\title{
An introduction to Mediterranean deep-sea biology*
}

\author{
FRANCISCO SARDÀ ${ }^{1}$, ANTONI CALAFAT ${ }^{2}$, M $^{\text {a }}$ MAR FLEXAS ${ }^{3,4}$, ANASTASIOS $^{2}$ \\ TSELEPIDES ${ }^{5}$, MIQUEL CANALS ${ }^{2}$, MANUEL ESPINO $^{3}$ and ANGELO TURSI ${ }^{6}$ \\ ${ }^{1}$ Institut de Ciències del Mar (CSIC). Passeig Marítim de la Barceloneta 37-49, 08039 Barcelona, Spain. \\ E-mail: siscu@icm.csic.es \\ ${ }^{2}$ GRC Geociències Marines, Dept. Estratigrafia, Paleontologia i Geociències Marines, Universitat de Barcelona, Martí i \\ Franqués s/n, 08028 Barcelona, Spain. \\ ${ }^{3}$ Laboratori d'Enginyeria Marítima, Universitat Politècnica de Catalunya (LIM/UPC), Campus Nord Mòdul D1, \\ Gran Capità s/n, 08034 Barcelona, Spain. \\ ${ }^{4}$ Institut Mediterrani d'Estudis Avançats (IMEDEA-CSIC), Miquel Marquès 21, 07190 Esporles, Mallorca, Spain. \\ ${ }^{5}$ Institute of Marine Biology, Hellenic Centre for Marine Research, Gournes Pediados, P.O. Box 2214, \\ 71003 Heraklion, Crete, Greece. \\ ${ }^{6}$ Dipartimento di Zoologia, Università di Bari, Via Orabona 4, 70125 Bari, Italy.
}

\begin{abstract}
SUMMARY: This chapter presents the state of the art concerning the deep-sea Mediterranean environment: geology, hydrology, biology and fisheries. These are the fields of study dealt with in the scientific papers of this volume. The authors are specialists who have addressed their research to the Mediterranean deep-sea environment during the last years. This introduction is an overview but not an exhaustive review.
\end{abstract}

Key words: Mediterranean, marine environment, geology, hydrology, biology, fisheries.

RESUMEN: INTRODUCCIÓN A LA BIOLOGÍA DEL MEDITERRÁNEO PROFUNDO. - Este capítulo presenta los conocimientos que actualmente se tienen sobre el ambiente del Mediterráneo profundo: hidrología, geología, biología y pesquerías, que constituyen el ambiente sobre el cual se han desarrollado las aportaciones de este volumen. Los autores son especialistas que durante los últimos años han dirigido sus estudios al mar profundo. Esta introducción pretende dar una visión general pero no ser una revisión exhaustiva.

Palabras clave: Mediterráneo, ambiente marino, geología, hidrología, biología, pesquerías.

\section{GENERAL TRENDS IN MORPHOLOGY AND SEDIMENTOLOGY}

\section{Introduction}

The Mediterranean sea, our ancient Mare Nostrum, Mare Internum or Mediterraneum ("sea between the lands"), is a relatively small but deep basin that is surrounded by continents (Shepard, 1963). The fact that it is landlocked between conti-

*Received June 9, 2004. Accepted October 20, 2004. nents conditions its general morphology, and the restricted communication with the open ocean is a major factor affecting the sedimentary dynamics and physical oceanography.

A great synthesis in the knowledge of the morphology, sedimentology and general geology of Mediterranean Sea came about with the presentation of synthetic bathymetric charts, as shown by Acosta et al. (2002). Bourcart (1960) made the first collection of bathymetric data in the Mediterranean Sea, for the western basin. Geological knowledge progressed further with the work of Carter et al. (1972) 
and the book "The Mediterranean Sea: A Natural Sedimentation Laboratory" edited by Stanley (1972), the International Bathymetric Chart of the Mediterranean (IBCM) of 1981 published by the USSR Ministry of Defence under the auspices of UNESCO, and the book "Geological Evolution of the Mediterranean Basin" edited by Stanley and Wezel (1985). The IBCM bathymetric contours and coastlines were incorporated into the worldwide digital atlas, the General Bathymetric Chart of the Oceans (GEBCO), drawn up by the British Oceanographic Data Centre (BODC). At present, the International Hydrographic Organisation (IHO) has assigned new areas of responsibility to the national hydrographic offices to obtain new detailed bathymetric maps using multibeam and long-range sidescan sonars. In some specific areas, regional geological work has made an important contribution to knowledge of the physiography and seafloor characteristics of the Mediterranean Sea: Pierrot (1972) for the Ligure Sea, Monti et al. (1978) for the western basin, Gennesaux and Vanney (1979) for the Algero-Provençal basin, Canals et al. (1982) for the northeastern Iberian margin, Bellaiche et al. (1980) for the deep-sea fan of the Rhone river, Canals et al. (2000) for the Valencia trough, and Berné et al. (1999 and 2002) for the Gulf of Lions.

The Mediterranean sea occupies an elongated basin, which was formerly part of the ancient Tethys Sea. It is $4000 \mathrm{~km}$ in length, and is located between $30^{\circ}$ and $46^{\circ} \mathrm{N}$ and $5.50^{\circ} \mathrm{W}$ and $36^{\circ} \mathrm{E}$ (excluding the Black Sea).

The western limit of the Mediterranean, the Strait of Gibraltar, is a shallow and narrow channel $320 \mathrm{~m}$ deep and $14 \mathrm{~km}$ wide and the only (natural) connection with the Atlantic Ocean. The northeastern limit connects the Mediterranean Sea to the Black Sea through the shallow and narrow channel in the Dardanelles, where the sill depth is $70 \mathrm{~m}$. The Mediterranean Sea and the Red Sea have been connected since 1869 by the Suez Canal.

Morphologically the Mediterranean Basin is subdivided by a series of transverse ridges with a north-south trend, parts of which emerge above sea level (Sverdrup et al., 1942). A submarine ridge between the island of Sicily and the African coast affects the primary division into the western and the eastern depressions. The sill depth in the strait between Sicily and Tunis is about $400 \mathrm{~m}$.

The western part is subdivided into three main submarine basins. The Alboran Basin is east of the Gibraltar Strait, between the coasts of Spain and
Morocco. The Balearic Basin or Algero-Provençal Basin, east of the Alboran Basin, is west of Sardinia and Corsica, extending from off the coast of Algeria to Provence in France. The Tyrrhenian Basin lies between the peninsula of Italy and the islands of Corsica and Sardinia .

The eastern Mediterranean is subdivided into two major basins. The Ionian Basin lies between the south of Italy and Greece and the coast of Libya, an area known as the Ionian Sea. A submarine ridge between western Crete and Barqah (Lybia) separates the Ionian Basin from the Levantine Basin to the south of Asia Minor. The Ionian Sea shows the deepest recorded point in the Mediterranean Sea, with $5121 \mathrm{~m}$ depth at the Hellenic Trough west of the submarine ridge (Vanney and Gennessaux, 1985). The island of Crete separate the Levantine Basin from the Aegean Sea, which comprises the area to the north of Crete and is bounded to the north and west by the coast of Greece and to the east by the coast of Turkey. The Adriatic Sea is a "cul-desac" basin (Vanney and Genesseaux, 1985) connected to the main water body by the Strait of Otranto, and is bounded by the peninsula of Italy to the west and north and by Croatia and Albania to the east.

\section{Geological structure}

The present-day structure of the Mediterranean basin results from the overall convergence of Africa and Eurasia, which involved several successive local rifting processes and collisions during the Tertiary.

In the eastern Mediterranean, part of the convergence is still accommodated by northward subduction Mesozoic Thetynian oceanic crust (Séranne, 1999). The active subduction in the Hellenic Trench system illustrates the final fragments of the Tethys Ocean, which may be in the latest stages of subduction below the European plate (Maldonado, 1985). In contrast, the western Mediterranean is floored by oceanic crust formed by extensional rifting during the Cenozoic time. This extensional basin was formed simultaneously with thrusting and mountain building in the surrounding areas, during continued northward motion of the African plate in relation to the Eurasian plate (Séranne, 1999).

The oldest Cenozoic basin of the Mediterranean Sea is the Balearic Basin, dating back to latest Oligocene or earliest Miocene from 28 to $5 \mathrm{Ma}$. The youngest basin is the Aegean Sea in the eastern Mediterranean, which mostly developed during the 
Pliocene and Quaternary, from 5 Ma to the Present.

With the emergence of the modern plate tectonics theory, it was attempted to assess the structure of the Mediterranean basins within this new context (Maldonado, 1985; Rehault et al., 1985; Vanney and Genneseaux, 1985; Roca et al., 1999; Séranne, 1999). Specifically, following the a criteria of tectonic stability, Vanney and Gennesaux (1985) subdivide the Mediterranean area into three geomorphic styles:

- Relatively stable regions such as the Pelagian Sea and the Gulf of Sirte in the central Mediterranean Sea and the Nilotic Front in the eastern Mediterranean Sea. This geomorphic setting results from deformation of the northern boundary of the African plate and alternation of periods of high clastic sediment supply during humid conditions and periods of construction of carbonate platforms during arid conditions.

- Unstable convergent regions, with an irregular and complex configuration related to the collision between the African and European plates. Four regions are included in this style: the Mediterranean Ridge, the Arc-Trench system, the Aegean Sea and the Adriatic Sea.

- Rifted cenozoic basins of the western Mediterranean and the Tyrrhenian basins formed by intrusion of oceanic crust and its cooling and contraction.

\section{Morpho-sedimentology}

From the sedimentological point of view the interesting feature of the geologic structure of marine basins is that their lower and lateral boundaries are formed of sediments. Furthermore, in all areas the depositional pattern is closely related to the surrounding topography, the sediment input and the oceanographic conditions (Maldonado, 1985). The importance of each of these factors differs for each depositional province, and each province is characterised by a series of depositional processes and controlling factors: 1) terrigenous shelves that predominate off major deltas, although there is a relative presence of calcareous-rich areas; 2) continental slopes dominated by the interplay between massgravity flows and hemipelagic settling; 3 ) areas with submarine canyons characterised by rapid sediment bypass to deeper basin zones; 4) base-of-slope deposits described as submarine fans and other types of fans; and 5) bathyal or basin plains with abundant deposits of hemipelagic muds on structural highs and protected areas, and turbiditic muds.
From the publication of the book "The Mediterranean Sea: A Natural Sedimentation Laboratory" by D. J. Stanley in 1972 to the present-day study of the sedimentology and stratigraphy of the Mediterranean basins we can provide a series of hot-spots that focus the interest of specialists: a) the Messinian salinity crisis; b) the presence and significance of sapropel layers; c) megaturbidites and their occurrence in the Mediterranean Sea; d) the phenomenon of "mud volcanism" with respect to degassing of deeply buried sediments; e) the role of catastrophic sediment failures in the configuration of continental margins; f) volcanism and its influence and use in the stratigraphic record; and g) the relationship between oceanographic structures and sedimentation. Some of these subjects will be introduced in the following sections in a more physiographical context.

\section{Continental shelves}

Mediterranean shelves represent less than 25\% of the total area. The continental shelves are modest around most of the Mediterranean Sea (Got et al., 1985). The main continental shelves are the Tunisian Plateau located off the Gulf of Gabes, between Tunisia and Libya, and the North Adriatic Sea off the Po delta. Excluding the Tunisian Plateau, which has a structural origin, the main wide shelves are related to the sediment supply from the main Mediterranean rivers. Examples of these are the Valencia shelf related to the Ebro river, the Gulf of Lions related to the Rhone river, the Adriatic shelf related to the Po river and the shelf in front of the Nile river. The offshore boundary of continental shelves, the shelfbreak or shelfedge, is defined by the change of gradient to the basin centre. This offshore limit is situated between 100 and $150 \mathrm{~m}$ depth, but reaches $260 \mathrm{~m}$ in the widest distance of the Nile continental shelf.

The narrow type of shelves is related to mountain belts surrounding the Mediterranean basin. These restricted shelves include the whole southern side of the Mediterranean basin, from Morocco to Turkey and Greece, only disrupted by the Tunisian Plateau and the Nile shelf. At the northern side of the basin, the southern shelves off Spain and the Balearic islands, the Corsica and Sardinia promontory and the southern shelves of the Italian peninsula are also included in the narrow shelves.

Sediments on the continental shelves show a configuration called a "sedimentary prism". The 
present sedimentary prism dates from 6000 B.P when the sea-level was nearly stabilised. This prism is divided into three different sedimentological provinces (Aloisi and Monaco, 1975; Got et al., 1985):

a) Littoral sands, or the inner shelf, supplied by rivers and shore erosion.

b) The shelf-mud belt, with a location at the middle shelf due to interaction between river input and prevailing long shore currents. In addition to this mud belt, in front of delta rivers a "pro-delta" is caused by deposition of muddy sediments with a laminated structure, alternating sandy and silty sediments that are rich in gas.

c) Relict sands at the outer shelf, deposited during the periods of low sea-level. In these zones the presence of relief is common due to erosion processes with cemented sand and gravels and sedimentary structures (sand-dunes, sand-waves...) produced by bottom currents.

This pattern of the distribution of shelf deposits according to the "sedimentary prism" model is consistent with the whole main river-influenced continental shelf mentioned above. The "sedimentary prism" model also emphasises two processes of sediment distribution: I) the role of sea-level change; and II) the relationship between residual currents and deposition of fine-size sediments as the "mud belt". The cyclic changes of climate between cold and warm periods and the subsequent sea-level changes greatly affect the continental shelf deposition. During the last low sea-level stage, $100 \mathrm{~m}$ below the present sea-level 18000 years BP, the outer continental shelf was subaerially exposed and eroded and the sediment inputs were deposited directly within the upper slope and submarine canyons. The sea-level rise until the present high sea-level stage, 6000 years BP, led to a preferential deposition of fine river sediments in the coastal and inner shelf zones, and with the decreasing rate of sea-level rise the sediments were trapped on deltas and the continental shelf and the "sedimentary prism" was established.

After the works of Aloïsi et al. (1975, 1979, 1980, 1982 and 1986), the model of a system of several nepheloid layers (turbid layers with higher concentrations of suspended particulate matter) was accepted. The importance and distribution of the nepheloid layers (surface, intermediate and bottom) are related to the hydrologic structure of the water column and the supply of terrigenous sediments. The bottom nepheloid layer (BNL) shows a 3D internal structure, a vertical stratification with increasing concentrations from the upper limit to the base and a seaward decreasing grain size. This bottom nepheloid layer can connect the inner shelf to the submarine canyon heads and the shelfbreak (Aloïsi et al., 1982; Calafat, 1993; Puig and Palanques, 1999). The BNL at the coastal and inner shelf zones has a composition rich in labile organic matter and nutrients of fluvial origin (Naudin and Cauwet, 1997) that are useful for feeding by benthic organisms. However, the high organic carbon content and the high sedimentation rates lead to a limited oxygen penetration in the surficial sediment and the formation of sapropels or layers with high organic carbon contents.

On the outer shelf and shelfbreak zones, the BNL is also fed by organic detritus and carbonate debris of pelagic origin (Naudin and Cauwet, 1997). This nepheloid layer has become the main food supply for benthic organisms (Fèral et al., 1990).

\section{Continental slope}

The continental slope represents the step zone between the outer shelf and base of slope or the basin plain. The steepness of the slope and its relation to the continental shelf serves to define the three main types of continental margins: progressive, intermediate and abrupt (Stanley, 1977). Margins located in front of or near to the main rivers are of the progressive type, showing a continuity of seismic reflectors.

Deposits on the continental slope are mainly fine-grained sediments. These sediments form a variety of deposits caused by various transport processes, from settling of suspensions to massgravity flows. Stanley and Maldonado (1981) propose a by-pass model of fine-grained sediments deposited by gravitational processes, which produce a progressively less dense flow (from slumps to low concentration turbid layers) and a final sediment characterised by a textural homogenisation (unifites) on the basin plains.

Landsliding is of prime importance in shaping and mobilising huge quantities of sediment downslope on both active and passive continental margins. Landsliding modifies the distribution pattern of canyon-channel systems and channel-levee complexes and thus the sedimentary architecture of continental margins (Canals et al., 2000).

Swath bathymetry techniques in addition to very high resolution reflection seismic profiles, side- 
scan sonographs and sediment cores are the methodologies used to study the seafloor and subseafloor features resulting from a large debris flow event that affected the continental slope and baseof-slope. Canals et al. (2000) and Lastras et al. (2002) show the structure of a debris flow named BIG'95 on the Ebro continental slope that disturbs more than $2200 \mathrm{~km}^{2}$, including a $26 \mathrm{~km}^{3}$ deposit of remobilised sediment. In the source area, the headwall scar located on the lower continental slope at ca. $1000 \mathrm{~m}$ water depth is $20 \mathrm{~km}$ long and up to 200 $\mathrm{m}$ high, and several other shallower secondary scars have been identified. Material released from these secondary scars partially buried the main headwall. Additional landslides, which occurred soon after the initial instability event, added more material to the debris flow deposit. The process of formation of the different scars and the releasing of material led to a rejuvenation of the slope relief, truncating canyons, burying the Valencia Channel and destroying gullies present in the rest of the continental slope and base of slope. Following the formation of the main headwall, large blocks of sediment were detached. These large blocks moved downslope while essentially keeping their internal coherence. Meanwhile, looser material from the slope moved in a different way and faster than the blocks, first partially burying the scars from which the blocks were detached, and then flowing through the depressions between the blocks. The decrease in the slope gradient and the Balearic margin counterslope slowed down the debris flow, stopping the blocks, after a run-out in excess of $20 \mathrm{~km}$. Looser material flowed farther on, reaching the distal depositional area, slightly climbing over the lowermost Balearic slope, and turning NE before burying part of the Valencia Channel after more than $100 \mathrm{~km}$ of run-out from the source area.

Dating sediment cores gives a minimum age of 11000 calendar years BP for the BIG'95 debris flow. A set of triggering mechanisms, including seismicity and oversteepening of the slope due to the existence of a volcanic structure underneath the main headwall, is invoked.

The main morphology of the continental slope is the submarine canyons. The submarine canyons are submarine valleys that are mostly incised in the continental slope and form part of the drainage system of continental margins. The upper course and head of some canyons can be cut, however, on the continental shelf and even reach the coastline (e.g. the Blanes and Palamós canyons in the northwestern
Mediterranean). The cross-section tends to be Vshaped along the upper course and U-shaped in the lower course, thus reflecting the prevalence of erosion and accumulation processes respectively. The course of submarine canyons is from straight to sinuous or even meandering, as is perfectly exemplified by the Rhone Canyon and channel off the Gulf of Lions, the Blanes Canyon off Spain, and others. An intriguing inner course incised into a major course is a rather common feature, as was recently observed in the northwestern Mediterranean thanks to full coverage swath bathymetric mapping (Berné et al., 1999; Canals et al., 2000).

Submarine canyons are widespread in many continental margins, but their density and development vary greatly. Complex canyon networks (e.g. the Gulf of Lions) are sometimes close to margin segments with only linear canyons (e.g. the Catalonia margin) or no canyons at all (e.g. the North Balearic margin).

The origin of submarine canyons is probably not unique, since different canyons might have different origins, either submarine or subaerial, or both (Canals et al., 2002). The notion of submarine canyons as stable features must be discarded, since they are born, evolve and eventually die by sediment starvation or sediment filling. Controlling factors such as weakness zones, fault planes and river mouths is known to play a major role in the location of some submarine canyons.

Transport of sediment downcanyon is enhanced during the low sea-level periods but little is known about the frequency of turbiditic flows in different canyon settings. Most canyons are relatively inactive at the present high sea-level time, but recent studies show that the sediment transport by nepheloid layers at the head and upper reaches of active canyons is related either to flood events in nearby rivers or to storm events increasing orbital velocities and enhancing density-driven currents (Puig et al., 2000).

During the 1990s, both European (EUROMARGENB, EUROMARGE-AS, CINCS, MATER...) and national projects conducted downward flux studies at selected sites along several Mediterranean continental margins. The main objectives addressed in these projects were to identify the mechanisms that control the particle fluxes on continental margins with distinct geological characteristics, inside and outside canyons, and to estimate flux budgets and mass balances. The experiments conducted over the entire Mediterranean basin, from the Alboran Sea to the Aegean Sea, made it possible to define the major 
features of shelf-to-slope particle transfer in the Mediterranean basin. The results are summarised in several publications (Fabres et al., 2002; Lipiatou, 1997; Lipiatou et al., 1999; Monaco et al., 1990; Puig and Palanques, 1998a; Stavrakakis et al., 2000; Tselepides and Polychronaki, 2000; and Monaco et al., 2002). All the studied margins show similar patterns, with the flux of particles in the continental margin environment showing an offshore decrease and depth increase. The increase in fluxes with depth is caused by lateral inputs. This supplementary arrival of particles represents a substantial contribution ranging from $50 \%$ in the Gulf of Lions to $80 \%$ in the Cretan Sea, though as an exception to this pattern Fabres et al. (2002) reported an opposite trend in the Malaga margin of the Alboran Sea. The changes in total mass fluxes over time fluctuate from a short scale of a few weeks (flux peaks) to a seasonal time scale (winter fluxes higher than summer fluxes). Increases in total mass fluxes are fairly simultaneous and are affected by driving forces that are either external (e.g. river discharges and storms) or internal (e.g. circulation patterns). The composition of settling material is relatively stable, with a predominant lithogenic component, even at the Baleares and Crete sites without a major fluvial supply; biogenic constituents (organic matter, calcium carbonate and biogenic silica) vary according to the location and period of the year and their variability decreases downstream due to the increase in total mass flux.

Submarine canyons draining sediments from the continental shelf and upper slope help to build various types of depositional bodies at the base-ofslope, mainly deep-sea submarine fans. Deep-sea submarine fans are thick sedimentary bodies that develop seaward of a major sediment input. They have gradients similar to continental slopes, decreasing from the upper to the lower fan. They are supplied with sediment by one or more feeder channels, usually connected to slope canyons or canyonchannel systems. The major deep-sea submarine fans are the Rhone and Ebro fans in the western Mediterranean, and the Nile fan in the eastern Mediterranean. Channels in submarine fans are flanked by levees, the positive reliefs formed by the overspill from channelised turbidity currents.

Turbidity currents are gravity-driven suspensions of mud and water. Beds deposited by turbidity currents are called turbidites. Turbidity currents may be caused by flood river discharges, storms, breaking of internal waves and (often) slope failure. Tur- bidites show a characteristic sequence of fining grain size and vertical disposition of sedimentary structures, which record the decrease in flow velocity. Turbidity currents can transport large volumes of sediments from the continental margin to the deep sea in a single event.

\section{Abyssal plains}

Abyssal plains are defined by several isobaths in the western and eastern Mediterranean. In the western basin the $2600 \mathrm{~m}$ (Stanley, 1977) and $2700 \mathrm{~m}$ (Rehault et al., 1985) depths have been used as upper limit, with a maximum depth of $2855 \mathrm{~m}$ to the east of Corsica. The abyssal plain is the largest physiographic feature in the western Mediterranean Basin, the vast area known as the Algerian-Balearic Basin, bounded by the $2600 \mathrm{~m}$ isobath (Acosta et al., 2002). Roughly, the basin has a triangular shape. Its vertices are the Oran Rise, the Ligurian Trough and the Sardinia Channel. The overall area is ca. $240000 \mathrm{~km}^{2}$. Previous works define this abyssal plain as in general "featureless" due to depositional processes (Rothwell et al., 1998), though other authors (Stanley et al., 1974 and Acosta et al., 2002) indicate low seafloor reliefs (up to $35 \mathrm{~m}$ height) ascribed to diapiric intrusions of the Miocene infrasalt layer and/or to basement irregularities.

In contrast with the Balearic Abyssal Plain, for the Tyrrhenian Bathyal Plain Selli (1985) choose the term bathyal due to the gentle concave shape, high sedimentation rates and the intermediate type of underlying crust, showing a flat sea-floor surface resulting from turbiditic deposition. The deepest part of this Central Tyrrhenian Basin exceeds depths of $3600 \mathrm{~m}$ (Vanney and Gennessaux, 1985). The Tyrrhenian bathyal plain is spotted by seamounts that rise from the bathyal plain. These correspond to volcanic bodies of tholeitic petrology associated with crustal faults oriented N-S, such as Magnaghi, Vavilov and Marsili seamounts, or to crescent-shape bathymetric ridges (hosrts) bounded by normal faults, such as Vercelli and Cassinis ridges (Wezel, 1985).

In the eastern basin, the Ionian Abyssal Basin, recording effects of compression, shows a sharp, small and broken topography for the basin plains. This abyssal plain shows a triangular form constrained by the Calabrian arc from the northwest, by the Mediterranean ridge from the east and by the folded system of the Sirte rise and the megafault system of the Sicily-Malta escarpment (Finetti, 1985). Specifically, the Ionian Abyssal Plain is sub- 
divided into three sub-basins, the Messina Plain the northern basin, and is delineated by the $3600 \mathrm{~m}$ isobath that reaches a depth of $4100 \mathrm{~m}$, the Sirte Plain located to the west of the Mediterranean Ridge (3900 m) and the Herodotus Trough, which is a narrow faulted depression (3000-3500 m depth) at the base of slope of Libya.

The Hellenic Trough is located between the Mediterranean Ridge and the western continental margin of Greece. This abyssal plain is defined by the isobath of $-3000 \mathrm{~m}$ (Carter et al., 1972). The floor of this plain shows a complex structure due to a combination of crustal plate kinematics with halokinesis and gravity processes. The floor is defined by a series of discontinuous mounts and trenches. Trenches are irregularly shaped depressions in echelon, forming small sediment ponds at different levels. These depressions, such as the North Matapan-Vavilov Trench which reaches a depth of $5121 \mathrm{~m}$ (Vanney and Gennessaux, 1985), are the deepest places in the Mediterranean.

The Aegean Sea is characterised by a basin deepand-shallow platform pattern (Vanney and Gennessaux, 1985). In this context, the Cretan Trough, the largest and deepest of the Aegean basins, is an elongated depression deepening from west $(1300 \mathrm{~m})$ to east $(2500 \mathrm{~m})$ parallel to the Cretan Island Arc (Crete, Kasos, Karpathos and Rhodes islands).

The Levantine basin has several abyssal plains bordering the Mediterranean Ridge. The Herodotus Abyssal Plain is located between the Mediterranean Ridge and the African continental margin, while the Rhodes Basin, the Antalya Basin and Cyprus Abyssal Plain are bordered to the north by the Turkish continental margin and to the south by the Mediterranean Ridge. The Herodotus Abyssal Plain, the largest basin plain in the eastern Mediterranean, is a NE-SW elongated depression bounded by the isobaths of 2800 or $3000 \mathrm{~m}$ with a maximum depth of $3156 \mathrm{~m}$ (Carter et al., 1972; Rothwell et al., 2000), lying seaward of the northwestern part of the Nile Cone (Rothwell et al., 2000).

Deep-sea plains commonly form the ultimate store of redeposited muds caused by instability on adjacent margins. Sediments filling the Mediterranean abyssal plains have been dominated by the deposition of turbidites. Two main controls have been identified, affecting sediment remobilisation and redeposition in the Mediterranean Sea (Rothwell et al., 2000): (1) climate change, principally linked to Quaternary glaciations, causing large-scale eustatic regressions and transgressions; and (2) the tectonic framework resulting from the long-term northward movement of the African plate into Europe. However, after Stanley (1985), the dominant control of Plio-Quaternary sediment thickness, sediment types, basin plain depth and margin configuration is geologically recent tectonic activity rather than sedimentary processes. An exception is the Mediterranean margin, which is affected mainly by riverine supplies (Nile, Rhone, Po, and Ebro rivers). Rothwell et al. (1998 and 2000) reported that some large-volume thick mud beds, called "megaturbidites", were transported by turbidity currents to the deep sea basins during glacial times. Thick structureless turbidite muds have long been reported from cores of Mediterranean troughs and basins (see references in Stanley, 1985). However, thick, laterally extensive 'megabeds' that are clearly very large-volume pounded mud turbidites have been described from the larger abyssal plains of the Mediterranean, on the western Mediterranean and Calabrian Ridges (Kastens and Cita, 1981), on the Ionian Abyssal Plain (Hieke, 1984), on the Herodotus Abyssal Plain (Cita et al., 1984 and Rothwell et al., 2000), and on the Balearic Abyssal Plain (Rotwell et al., 1998 and 2000).

Below the pelagic and hemipelagic (megaturbidites) Plio-Quaternary sediments (more than 1000 $\mathrm{m}$ thickness), extremely thick evaporitic sediments (from 2000 to $3000 \mathrm{~m}$ thick) were deposited. In 1970, Leg 13 of the Deep Sea Drilling Programme (DSDP) discovered that evaporitic deposits of Messinian age (5-6 million years ago) are present in the sub-bottom of all the major basins of the Mediterranean (the Balearic, Tyrrhenian, Ionian and Levantine basins) (Ryan et al., 1973). In 1975, Leg 42 showed that the evaporític deposits were not restricted to the shallow marginal basins but were widespread in all of the deeper Mediterranean basins, as was imaged by basinwide seismic profiles and sampled by drilling. According to Hsu et al. (1973), during the Messinian, the Mediterranean Sea became isolated from the Atlantic Ocean, which caused some areas to dry out and large salty lakes recharged by rivers flowing through deep canyons replaced the previous marine basins (Hsü et al., 1973; Hsü et al., 1973b; Cita, 1991; MacKenzie, 1999). This was the so-called Messinian salinity crisis. During this low sea level event, the emerged Mediterranean margins were subjected to intense erosion. The erosional surfaces that formed during the Messinian are quite varied, and a complex network of canyons incised the continental margin. 
Plio-Quaternary pelagic and hemipelagic sediments drape the entire margin, recording the wide effects of the post-Messinian sea level rise (Rehault et al., 1985). This explanation of the Messinian salinity crisis led to one of greatest controversies (Cita, 1991) in the geological community. The significance of Messinian events can be judged from the estimate that as much as $6 \%$ of the ocean's salt was transformed into giant deposits left on the Mediterranean sea floor by evaporation (MacKenzie, 1999). Krijgsman et al. (1999) show that the onset of the Messinian salinity crisis was synchronous over the entire Mediterranean basin, and date it at 5.96 million years ago. Isolation from the Atlantic Ocean was established between 5.59 and 5.33 million years ago, causing a large fall in the Mediterranean water level followed by erosion (5.59-5.50 million years ago) and deposition (5.50-5.33 million years ago) of non-marine sediments in a large 'Lago Mare' (Lake Sea) basin.

The water column of the present Mediterranean is characterised by oxygenated conditions above the sea-floor, as is indicated by the yellowishbrown bioturbated surface sediments in most regions (Stanley, 1985). However, the alternating sequences of light and dark sediments in Plio-Quaternary cores indicate that this condition was different in the past. The dark, organic rich muds are known as sapropels, which are common in eastern Mediterranean sections, if the percentage of organic carbon is greater than $2 \%$, and as sapropelic sediments or organic-rich layers, which are found in some western Mediterranean sites, if the organic carbon content is between 0.5 and $2.0 \%$. These petrologic changes could to record successive oxic-anoxic events. Two main models have been put forward to explain the origin of sapropels (Martínez-Ruíz et al., 2003): (1) the 'stagnation model', involving external physical processes (temperature, evaporation, circulation) that caused intense vertical density gradients, resulting in stable stratification, reduced ventilation of deep water and anoxia, thus enhancing organic matter preservation; and (2) the 'productivity model', involving increased export production and rapid supply of organic matter to the sediment, which caused great remineralisation, leading to increased organic matter burial and low oxygen in deep waters. A combination of the two models, bottom water anoxia and increased productivity, has also been suggested. Local geographical settings and circulation patterns may, however, have induced various respons- es to regional climate changes in different Mediterranean basins over time. This is supported by significant differences in the sedimentary records of the eastern and western Mediterranean sapropel event (Martínez-Ruíz et al., 2003).

\section{WATER MASS CIRCULATION IN THE WESTERN MEDITERRANEAN BASIN}

\section{Introduction}

The topographic characteristics of the Mediterranean basin force one to make a separation between the western and eastern Mediterranean basins, which are divided by the relatively shallow Strait of Sicily. The larger seas contained in the western Mediterranean Sea are the Alborán Sea, the Algerian, the Tyrrhenian, the Liguro-Provençal and the Catalan or Balearic (Fig. 1).

The $200 \mathrm{~m}$ depth isobath is commonly used in the western Mediterranean to separate the continental shelf from the continental slope. The width of the continental shelf is quite variable, sometimes being particularly wide, as occurs in the Gulf of Lions (Fig. 1). In these wide and relatively shallow regions, sea breezes, strong northern winds and storms can greatly influence the flow, in contrast to waters beneath the $200 \mathrm{~m}$ isobath. The continental slope separates the continental shelf from the deep sea; it is a relatively narrow zone in which the change from $200 \mathrm{~m}$ down to $2000 \mathrm{~m}$ depth occurs within a few tens of kilometers.

The main water masses that can be found in the western Mediterranean basin are the Atlantic Water (AW), the Levantine Intermediate Water (LIW), the Tyrrhenian Deep Water (TDW), and the Western Mediterranean Deep Water (WMDW). Surface waters and intermediate waters have their origin in waters coming from the Atlantic and from the eastern Mediterranean respectively. Thus, the surface dynamics in the Mediterranean Sea relies on the exchange of water masses through the Strait of Gibraltar: low dense Atlantic waters intrude as surface waters in the Mediterranean, while denser Mediterranean waters travel beneath in an opposite direction into the Atlantic ocean. Furthermore, an exchange of intermediate waters takes place in the Strait of Sicily. Due to topographic constraints, deep water masses have only a local origin: the formation of TDW is due to mixing, caused by the intrusion of LIW into the Tyrrhenian Sea by cascading from 200 


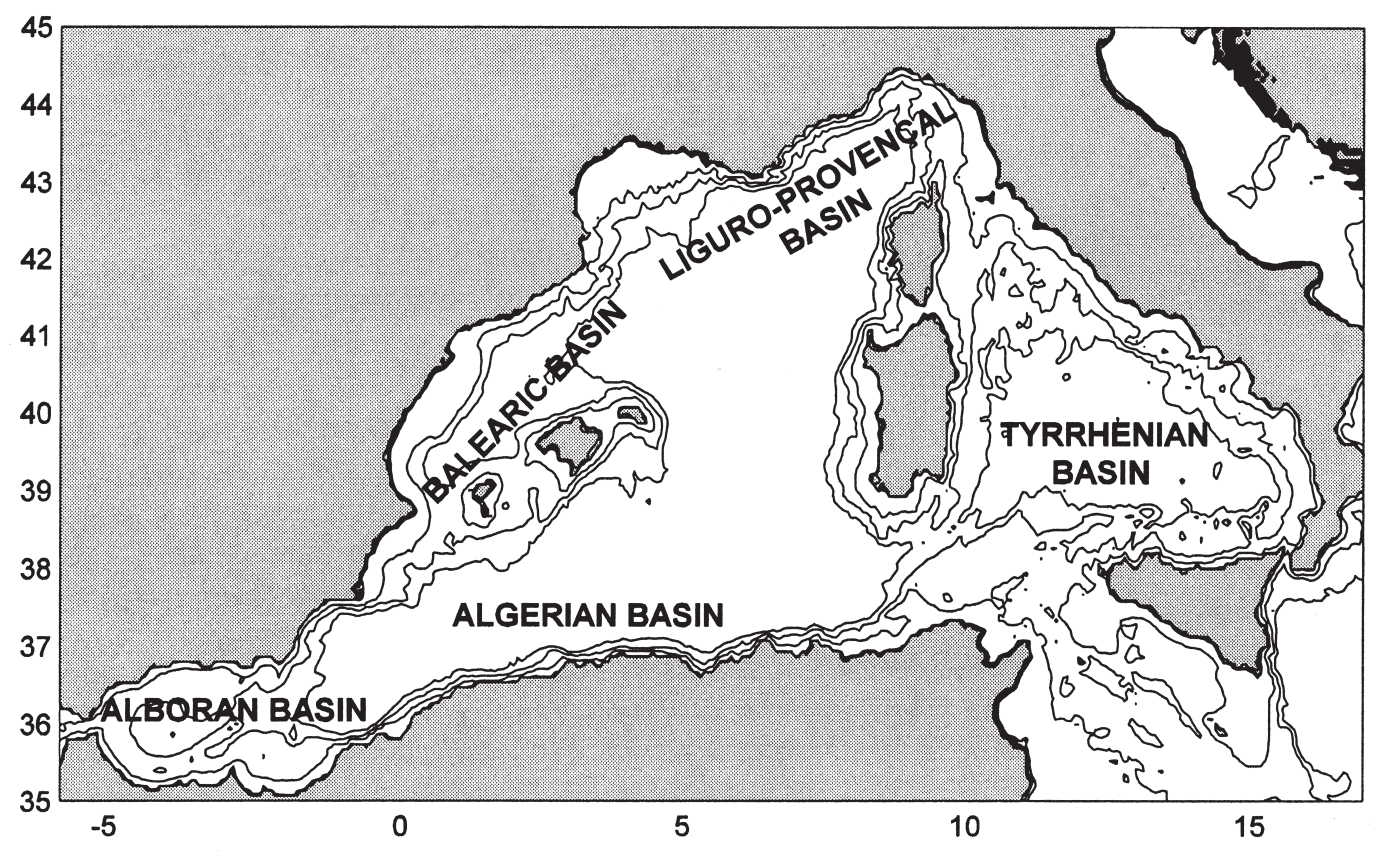

FIG. 1. - Western Mediterranean Sea sub-basins (deg. North and East are positive).

m to nearly $1800 \mathrm{~m}$ depth; the WMDW is caused by cell convection during severe winters in the northern part of the western basin.

The marine circulation along the western Mediterranean continental shelves and slopes is far from simple and well understood. During late spring and summer, the whole western Mediterranean is strongly stratified. The seasonal thermocline is $20-$ $50 \mathrm{~m}$ deep. In winter, the water column is rather homogeneous, especially in the open sea. The isolated and combined action of several factors like strong winds, the presence of shelf-slope density fronts and a complex bottom topography due to the existence of a sloping bottom and submarine canyons lead to complicated circulation patterns. Mesoscale variability, defined as the ensemble of flow fluctuations whose periods range from the order of a few days to a few tenths of days, is responsible for small gyres or vortices (i.e. mesoscale eddies) which are observed to modify the general circulation in the western Mediterranean basin. Among other characteristics, they are able to block the general circulation, they are supposed to contribute to the exchange between the continental shelf waters and slope waters, and they are associated with vertical motions that allow water and nutrients to rise or sink, thus having strong biological, geological and chemical implications.

A review of the circulation of the different water masses present in the western Mediterranean basin reveals that major contributions have focused on the study of surface currents. Deep and bottom currents, especially those outside the geostrophic assumptions (like bottom current intensifications), are more unknown. A similar conclusion is reached concerning the origin of the different water masses. Nowadays, a special effort is devoted to studying the processes and mechanisms of deep and bottom water formation and revealing new insights. Furthermore, the variability of the deep currents is of major interest, since it may be relevant for the ventilation of the deep western Mediterranean Sea. Therefore, further studies about the formation mechanisms and behaviour of the large and mesoscale variability of the deep currents are needed. In this review we outline the main characteristics of the origin and circulation of the above-mentioned water masses.

\section{Surface water masses}

\section{Atlantic Water}

The origin of the circulation in the Mediterranean Sea relies on its sole connection to the open ocean, the Strait of Gibraltar, a shallow and narrow aperture that connects the Mediterranean to the Atlantic Ocean. The Strait of Gibraltar allows a selective renewal of Mediterranean Sea waters. Low-density Atlantic waters intrude into the 
Mediterranean as surface waters, while denser Mediterranean waters (high salinity waters due to low fresh-water supplies and high evaporation) travel at mid-depths into the Atlantic Ocean.

The inflow of Atlantic waters spreads along the Algerian coast, resulting in a general anticlockwise flow. This surface water of Atlantic origin is modified during its journey along the Mediterranean coasts, acquiring different thermohaline characteristics - it becomes saltier and therefore denser.

The intrusion of Atlantic water into the Alborán Sea draws two anticyclonic gyres, from which only the most westward gyre shows a permanent anticyclonic motion. The most eastward gyre is more variable, and although most of the time it shows up as anticyclonic, it has also been recorded as cyclonic (Viúdez and Tintoré, 1995). When the most eastward gyre is depicted as anticyclonic, its easternmost circulation branch that joins the Iberian peninsula to Algeria is named the Almería-Orán front. Small cyclonic gyres have been observed to be linked to both anticyclonic gyres.

In its eastward flow, the AW flows into the Algerian basin as the Algerian current, a relatively narrow and deep current 30-50 km wide and 200$400 \mathrm{~m}$ deep at the coast, which becomes thinner (in depth) and wider (in horizontal extension) eastwards (Benzohra and Millot, 1995). The Algerian current flows following the Algerian slope to the Channel of Sardinia. The instability of the Algerian current leads to the development of a series of coastal eddies. Although both cyclonic and anticyclonic motions have been observed, only the anticyclonic gyres last for a long time, i.e. for weeks or months. These gyres are associated with a non-wind-induced upwelling. The vertical extent of these mesoscale coastal eddies is what remains more uncertain. The Algerian current and its mesoscale phenomena have been considered as a whole, i.e. as a system in which the Algerian current meanders due to its unstable character and generates a coastal mesoscale eddy and a large eddy in the deeper layer, with both axes initially not centred (Millot, 1994). This motion has been successfully reproduced in the laboratory by Obaton et al. (2000).

The flow of the Algerian current following the Algerian slope can be blocked by the presence of open sea eddies. The interaction of the Algerian current with an open sea eddy can deviate the Algerian current from the Algerian slope directly towards the Balearic Islands (Taupier-Letage and Millot, 1988). These open sea eddies are considered as late stages of coastal eddies. Their eastward progression is topographically constrained by the Channel of Sardinia, where such deep structures are forced to flow northwards, contributing to the unstable flow west of Corsica, before finally turning westwards to return into the Algerian basin. The extension of recent AW from the Algerian basin into the Balearic basin is delimited by the North-Balearic front.

A branch of AW enters from the Algerian basin into the Tyrrhenian Sea, whereas a second branch continues its path to enter the eastern Mediterranean (Font et al., 1998). A part of the former directly returns to the western Mediterranean as part of the Tyrrhenian surface outflow (Astraldi et al., 2002). An occasional cyclonic eddy is placed in the northern part of the Tyrrhenian Sea, and is associated with an upwelling induced by westerly winds. The AW flows through the Channel of Corsica with a significant seasonal and annual variability of the flux, which is attributed to the atmospheric conditions over the Liguro-Provençal basin (Astraldi and Gasparini, 1992).

The northward currents on the east and west coasts of Corsica join to form the Northern Current, which flows mainly following the continental slope in the Liguro-Provençal basin. Part of the flow is directed southwards along the coasts of Sardinia into the Algerian basin, giving the Algerian basin a supply of AW apart from the new AW intruding from the Alborán sea. In the Liguro-Provençal basin, the Northern Current flows following the continental slope along the French coasts and the Iberian peninsula to the Channel of Ibiza, and flows perpendicularly to a thermal front (the Pyrenees front) that separates cold waters from the Liguro-Provençal basin from warmer waters from the Balearic basin. This front shows seasonal variability and has its origin in the cold and strong northwesterlies blowing in the Liguro-Provençal basin, which are blocked by the Pyrenees and therefore damped in the Balearic basin.

The Northern Current flows along the 1000 to $2000 \mathrm{~m}$ isobaths at its entrance into the Gulf of Lions. It is a $30-50 \mathrm{~km}$ wide current with surface speeds of $30-50 \mathrm{~cm} \mathrm{~s}^{-1}$. Formally, this current involves AW, LIW, TDW and WMDW, although horizontal velocities are very low below $400-500 \mathrm{~m}$ depth. In addition, the presence of a density front that separates continental waters from slope in the Gulf of Lions and all along the eastern coasts of the Iberian peninsula reinforces the surface signature\$ of the Northern Current by geostrophy. During the 
winter the Northern Current is observed to flow closer to the continental slope, showing a narrower and deeper structure. Its major variability occurs in two period bands of 2-5 days and 7-10 days at the entrance of the Gulf (off Marseille), occurring in slightly longer periods (bands of 3-6 days and 10-20 days respectively) upstream (i.e. off Nice). The meandering amplitude of the 3-6 days band is of 30$60 \mathrm{~km}$ wavelength, with propagation speeds of 10 $\mathrm{km} /$ day, whereas the 10-20 day variability band (observed to reduce to a 10 day variability band in spring) has been mostly associated with Northern Current pulses. There is offshore advection of mesoscale variability associated with the Northern Current towards the open sea, mainly of cyclonic sign. The origin of the mesoscale variability of the Northern Current has been normally associated with baroclinic instability, although other processes such as barotropic instability may also play a role in the observed variability (Flexas, 2003; Jordi et al., in press).

Once in the Balearic basin, at its southernmost extent, the Northern Current is divided into a flow along the northern coasts of the Balearic Islands and a southward flow intruding the Alborán Sea. The latter flow completes the entire 'cyclonic' gyre of the AW.

\section{Western Mediterranean Intermediate Water}

During winter, the northwestern Mediterranean Sea is characterised by strong cold northwesterly winds. When these winds are persistent and strong they can cool the surface AW so it becomes denser and sinks. This newly-formed water will be overlaid by AW from the surroundings and will receive the name of Western Mediterranean Intermediate Water (WIW). Therefore, this winter mechanism produces a water with the same characteristics as the AW but with a minimum temperature located just beneath the AW. This mechanism of formation was proposed by Conan and Millot (1995). The formation of WIW is common in the whole northwestern Mediterranean sea in winter, but the coldest WIW is found in the north. The WIW follows the AW along the continental slopes of France and the Iberian peninsula to finally intrude into the Algerian basin, although it can also be introduced directly from the Gulf of Lions if it interacts with eddies associated with the North-Balearic front.

The formation of WIW has special importance in the mixing of AW with the underlying water, the
LIW: since the WIW has intermediate characteristics between AW and LIW, the presence of WIW will facilitate their mixing.

\section{Intermediate and deep water masses}

Levantine Intermediate Water, Eastern Mediterranean Deep Water and Tyrrhenian Deep Water

The Levantine Intermediate Water (LIW) flows under the AW and the WIW. This intermediate water has its origin in the eastern Mediterranean basin and is introduced in the western Mediterranean basin through the Channel of Sicily. It has a maximum temperature and salinity below $200 \mathrm{~m}$ depth.

The usual hypothesis of Tyrrhenian Deep water (TDW) formation was that it originates though a mixing of newly entered LIW from the eastern basin and 'old' LIW which has been travelling along the western Mediterranean and is returning from the Algerian basin to the Tyrrhenian Sea. This has been recently disregarded (Fuda et al., 2002) and instead a hypothesis of dense water formation occurring within the Tyrrhenian Sea has been proposed.

Recently, in the Strait of Sicily a cold dense vein of slightly different characteristics flowing beneath LIW directly over the sea bottom and following the LIW path has been observed. This water is present in the Ionian Sea between the LIW and the Eastern Mediterranean Deep Water (EMDW). Recently, this vein has been referred to as transitional Eastern Mediterranean Deep Water (tEMDW) (Vetrano et al., 2004; Sparnocchia et al., 1999), Transitional Ionian Deep Water (Iudicone et al., 2003), and also EMDW (Astraldi et al., 2001). At the entrance to the strait this vein presents mean hydrographic characteristics of $\mathrm{T}=13.53^{\circ} \mathrm{C} ; \mathrm{S}=38.723 \mathrm{psu}$ and $\sigma_{\theta} \sim$ 29.17.

The LIW and EMDW enter the western Mediterranean from the eastern basin through the western side of the strait, along the Tunisian coast (Astraldi et al., 2001; Fuda et al., 2002). This occurs at a relatively shallow depth, at $\sim 300 \mathrm{~m}$, and below a strong LIW flow. The entrainment stress between AW and LIW plays an important role in the along-channel pressure gradients, which finally push the EMDW vain through the Sicily Strait (Astraldi et al., 2001). They then enter the Tyrrhenian Sea; there is no evidence of any current path from the eastern Mediterranean coming directly to the Sardinia Channel (Onken et al., 2003). When LIW decreases in velocity, the deep vein re-establishes its geostrophic posi- 
tion along the Sicilian coast, which is, due to its high density, at $\sim 1500-1800 \mathrm{~m}$ depth. This sinking causes strong mixing and increases the volume of TDW (Sparnocchia et al., 1999), which together with LIW forms the Tyrrhenian basin outflow at intermediate and deep levels.

The LIW and TDW follow the same path, flowing along the western coasts of Sardinia. On the southwest coast of this island, the LIW + TDW shows its maximum variability: from being a relatively narrow vein to the south of Sardinia, it becomes wider (in horizontal direction), thinner (in depth) and cooler to the west of the island. These changes have been attributed to the interaction with open sea Algerian eddies that migrate from the Algerian slope to open waters, and also to the inherent instabilities of the intermediate water vein, which is presumably able to generate anticyclonic structures. Millot (1999) proposed calling these anticyclones 'Leddies', similar to the naming of the Atlantic Meddies.

The LIW + TDW continue flowing along the continental slope of Corsica on an anticlockwise path similar to the AW, along the slopes of the Liguro-Provençal basin $\left(\mathrm{T}=13.4-13.5^{\circ} \mathrm{C}\right.$ and 38.50 $38.55 \mathrm{psu}$ ), only disturbed by occasional winter seaward spreading. Its general path continues along the continental slopes of the Iberian peninsula towards the Alborán Sea and part of it flows towards the Algerian basin following the Almería-Orán front or the westernmost Alborán anticyclonic gyre. Once there, the LIW + TDW is no longer present as a vein, but it still follows the Algerian slope until it interacts with an Algerian eddy and is exported northwards.

\section{Western Mediterranean Deep Water}

The deep water beneath the TDW is the Western Mediterranean Deep Water (WMDW). The WMDW is formed in the Gulf of Lions during severe winter conditions, due to cold Mistral and Tramontane wind events (MEDOC Group, 1970), by small convective cells or "chimneys" with high downward vertical speeds.

Its origin lies in vertical mixing produced by small plumes of the order of a few hundreds of metres in diameter with vertical velocities of the order of $10 \mathrm{~cm} \mathrm{~s}^{-1}$ that develop into convective cells with downward vertical speeds of $1 \mathrm{~mm} \mathrm{~s}^{-1}$ (Gascard, 1978). Eddies of a few $\mathrm{km}$ in diameter develop (due to baroclinic instability) and contribute to re-stratification. The WMDW does not form every winter: during mild winters this mixing process forms intermediate waters resting above $1500 \mathrm{~m}$ depth. The mean hydrographic characteristics of WMDW are $12.7-12.80^{\circ} \mathrm{C}$ and $38.44-38.46 \mathrm{psu}$, although they have been seen to change with a 10 year period, showing an increasing tendency in both salinity and temperature of $0.03^{\circ} \mathrm{C} / 10$ years and 0.02 psu/10 years (Millot, 1999).

Deep water formation has historically been divided into three phases: preconditioning, vigorous convection and relaxation (MEDOC Group, 1970). All three phases are spatially highly non-uniform and show mesoscale activity at short time scales, together with advection processes like intrusions of LIW and surface capping (Gaillard et al., 1997). Specifically, the preconditioning phase involves cooling of the water surface due to the effect of the cold N-NW winds and leads to a rising and tilting of the isopycnals, affecting the horizontal and vertical density distribution of the shelf-slope front.

Although deep water formation is mostly found to occur in the open sea, strong wind events (i.e. Mistral and Tramontane) occurring over the Gulf of Lions continental shelf can also lead to the formation of deep water. During severe winters, the wide continental shelf in the Gulf of Lions enhances deep water formation on the continental shelf. When this occurs, the newly-formed deep water spreads into the open sea perpendicularly to the continental slope, as a cascade, down to $1500 \mathrm{~m}$ depth. This cascading is important not only from a dynamic point of view but also in terms of biogeochemical cycles: during most of the year the Gulf of Lions continental shelf is a sink for nitrate, but during winter dense water cascading is responsible for nitrate exportation toward the open sea (Tusseau-Vuillemin et al., 1998).

The WMDW formed in the Gulf of Lions follows basically the continental slope at depths greater than $1500 \mathrm{~m}$. Once it reaches the Alborán Sea, part of the flow is released up to $300 \mathrm{~m}$ depth by mixing processes and part is introduced into the Algerian basin, where it continues flowing along the continental slope. In this region it acquires a general anticlockwise circulation. It is worth noting that close to the bottom, at about $2500 \mathrm{~m}$ depth, along-slope mean speeds are of the order of 3-4 $\mathrm{cm} \mathrm{s}^{-1}$, and they are greater than $1500 \mathrm{~m}$ above. It has been hypothesised (Millot et al., 1997) that this is due to the effect of the anticyclonic eddies, which are believed to induce intense currents in the whole deep layer and near the bottom. 
Recently, free-drifting float experiments revealed for the first time how WMDW newly formed in the Gulf of Lions was advected several hundreds of kilometres away by sub-mesoscale coherent vortices, SCVs (Testor and Gascard, 2003). The trajectories of some SCVs were observed to cross the western Mediterranean Sea from the Gulf of Lions down to the Algerian coasts over a period of 5 months. During their journey, SCVs are able to transfer newly formed WMDW properties to the ambient waters. The upper part of SCVs would be warmed by LIW, whereas the bottom part of SCVs would be cooled by old WMDW. In some cases (Testor and Gascard, 2003) the interaction of an LIW eddy with an SCV has been observed. These eddy-eddy interactions are thought to influence the large-scale spreading of intermediate and deep waters. Moreover, the advection of WMDW by SCVs implies a role in the large-scale thermohaline circulation and in the ventilation of the deep western Mediterranean Sea.

The Channel of Sardinia is a key place for WMDW circulation due to its bathymetry. On their way from the Algerian basin, those waters flowing above $2000 \mathrm{~m}$ depth will be able to flow into the Tyrrhenian Sea, whereas those flowing deeper than $2000 \mathrm{~m}$ will be forced to flow along the western continental slope of Sardinia.

\section{DEEP-SEA FAUNA AND BENTHIC FLUXES}

\section{Introduction}

Information on Mediterranean biogeography can be extracted from non-quantitative historical studies, but considerable caution is needed. During his investigations in the Aegean Sea, Forbes (1844) reported that life did not exist deeper than 300 fathoms (= ca $550 \mathrm{~m}$ ), and used the term "azoic zone" to describe his finding. This led to a misunderstanding which was not resolved until the beginning of the 20th century. Although Marenzeller (1893) reported that species occur deeper in the Levant than elsewhere in the Mediterranean, his records were later considered suspect, an artifact resulting from a «systematic mistake in the depth measurements» that «needs to be cleared up in the future» (Fredj and Laubier, 1985).

The present-day Mediterranean deep water fauna is less closely related to the Atlantic bathyal than was the case in the Pleistocene (Barrier et al., 1989).
This disparity is attributed in part to the shallow Gibraltar sill that bars the deep water of the Atlantic Ocean from entering the Mediterranean, and to the Mediterranean outflow that bars the entry of the deep water Atlantic fauna into the Mediterranean (Salas, 1996). The onset of warmer climates led to the demise of many cold stenothermic and stenohaline species and to the eventual impoverishment of the bathybenthos. In addition, the extreme oligotrophy of the Levantine Sea prevented settlement by members of the Atlantic bathyal that would have been able to cross the shallow Gibraltar Straits and the Siculo-Tunisian sill $(<400 \mathrm{~m})$ (Péres, 1985). The recurring stagnant (dysoxic and anoxic) Quaternary episodes resulted in a reduction, or even the extinction of deep bottom-living fauna unable to avoid annihilation by adapting to a shallower depth: Van Harten (1987) reported that «several species of deep-water ostracodes that are still common in the western Mediterranean became extinct in the eastern Mediterranean basin at the onset of early Holocene S1 sapropel deposition». Bacescu (1985) believed that the bathyal bottoms of the Levant are still «unfavourable», or even, «azoic», after the last sapropelic event, dated between 9000 and 6000 years BP, following the suggestion (George and Menzies, 1968) «that sufficient time has not elapsed to allow colonisation of the deep-sea floor».

Bouchet and Taviani (1992), in a very provocative paper, suggested that much of the Mediterranean deep-sea fauna is made-up of non-reproducing pseudopopulations that have entered the Mediterranean as meroplankton with the Atlantic inflow at Gibraltar. However, the populations of the most common benthic molluscs at depths greater than $1000 \mathrm{~m}$ in the Levantine Sea are composed of both adult and juvenile specimens. Moreover, gravid benthic decapod crustaceans and fish have been collected repeatedly from the depths of the Levantine Sea (Galil and Goren, 1994; Goren and Galil, 1997; Fishelson and Galil, 2001). Though much reduced in diversity and richness compared with the deep sea fauna of the western and central basins of the Mediterranean, the Levantine bathy-benthos appears to be composed of autochthonous, self-sustaining populations of opportunistic, eurybathic species that have settled there following the last sapropelic event.

\section{Macrofauna}

Despite the thorough review of Fredj and Laubier (1985) regarding qualitative aspects of the 
benthic macrofauna composition of the deep Mediterranean Sea, quantitative data from this basin are generally scarce or lacking. It is not an exaggeration to say that the vast majority of the deep Mediterranean basin is virtually unknown. Despite the interest of its fauna, the eastern Mediterranean, the deepest of the two basins, remained one of the most poorly studied areas of the world until the early 1990s. During the second half of the 20th century research was sparse, with only some general ecological and faunal surveys conducted in the Mediterranean providing scattered information (Pérès and Picard, 1958; Tchukhtchin, 1964; Ledoyer, 1969; Guille, 1970; Desbruyeres et al., 1972; Vamvakas, 1970 and 1973; Di Geronimo, 1974). The earliest records of macrobenthic organisms from the Cretan Sea were those given by Forbes (1844), Raulin (1870) and Jeffreys $(1881,1883)$. However, with the establishment of the Institute of Marine Biology of Crete, a number of benthic studies have appeared in the last twelve years (Tselepides, 1992; Tselepides and Eleftheriou, 1992; Koutsoubas et al., 1992, 2000; Tselepides, 1994; Karakassis and Eleftheriou, 1997; Eleftheriou et al., 1996; Tselepides et al., 2000), contributing significant information to the knowledge of the macrobenthic fauna mainly from the outer continental shelf to the upper and midslope of the island of Crete.

Until recently, however, knowledge of the deep (bathyal to abyssal) macrobenthic fauna remained sparse, derived primarily from material collected during the early "POLA" Expedition (1890-1893) in the eastern Mediterranean (Sturany, 1896) and to a lesser extent from the METEOR expeditions in 1987, 1993 and 1998 (Janssen, 1989; Fiege et al.,
1994, 2000; Ben-Eliahu and Fiege, 1996). It was not until recently (1987-2000) that a coherent sampling effort was undertaken, mainly within the framework of EU funded projects, but even so the number of reliable quantitative macrobenthic samples acquired is very low (probably less that 100), as most of these studies were conducted as part of large multidisciplinary biogeochemical projects and therefore little effort and time was devoted to sampling the benthic community.

Several investigations have described low-density and low-diversity conditions of marine invertebrates in the eastern Mediterranean (Pérès and Picard, 1958; Fredj and Laubier, 1985; Janssen, 1989; Tselepides and Eleftheriou, 1992; Tselepides et al., 2000). Por and Dimentman (1989) mentioned that a safe hypothetical figure concerning the impoverishment in the general diversity of the marine biota in the Levantine Basin would be $30 \%$. The bathyal muds of the Levantine basin have also been reported as being inhospitable or even azoic after the last "sapropelic event" (Menzies, 1962, 1973; George and Menzies, 1968; Bacescu, 1985). Tselepides et al. (2000), in the Cretan Sea, reported that mean benthic biomass, abundance and diversity (Fig. 2) decreased drastically with depth, with major faunal transitions occurring at 200, 500 and $1000 \mathrm{~m}$ depth. Unexpectedly, the western basin has also been grossly understudied, with very few quantitative studies focusing on the bathyal and abyssal macrofauna. A comprehensive quantitative approach was undertaken by Stora et al. (1999) with samples taken within and along the flanks of the Toulon Canyon. Other recent studies have focused mainly on functional aspects such as gradients of

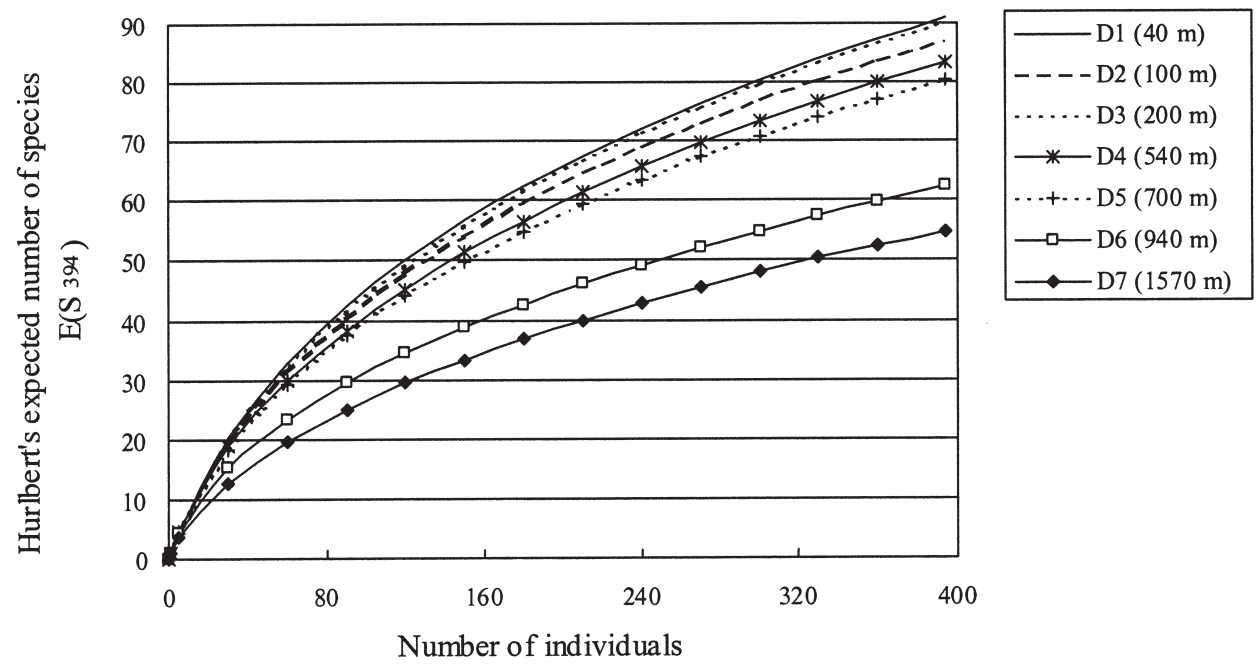

FIG. 2. - Hurlbert's expected number of species from the continental margin of Crete (from Tselepides et al., 2000). 
pelagic-benthic coupling, organic carbon mineralisation rates and environmental chemistry of deepsea sediments (Tahey et al., 1994; Danovaro et al., 1999; Duineveld et al., 2000; Guidi-Guilvard, 2002; Giordani et al., 2002). Cartes et al. (2001) gave valuable quantitative information regarding the community structure of the bathyal suprabenthos in the Catalan Sea, which showed relatively high diversity at mid-bathyal depths. Nevertheless, the deep Mediterranean holds interesting surprises. Although it is generally considered to be a "biological desert", times do come when certain areas display such high benthic activity as to be characterised as "benthic hotspots" (Boetius et al., 1996; Fiege et al., 2000; Danovaro et al., 2001; Hausmann et al., 2002; Lykousis et al., 2002; Tselepides and Lampadariou, 2004).

It is now well established that the basic factors responsible for the general impoverishment observed in the Mediterranean are: (i) its biogeographic and geological history, (ii) the high prevailing temperatures $\left(13-14^{\circ} \mathrm{C}\right)$ below $200 \mathrm{~m}$ depth, and (iii) the scarcity of food supply. Indeed studies of the eastern Mediterranean bathyal and abyssal fauna have revealed significant correlations between faunal (both meio- and macrofaunal) abundances and biomass, and factors indicating food availability, all being at very low levels compared to temperate regions (Pérès, 1982; Sarà, 1985; Soyer, 1985; Thiel, 1983; De Bovée et al., 1990; Tselepides, 1992; Tselepides and Eleftheriou, 1992; Danovaro et al., 1999, 2000; Tselepides et al., 2000; Tselepides and Lampadariou, 2004).

\section{Meiofauna}

Compared to other areas of the world, the Mediterranean Sea, and in particular the eastern basin, is considered to be one of the most oligotrophic areas in the world (Berman et al., 1984; Azov, 1986; Psarra et al., 2000). Several authors have related the oligotrophy of the eastern Mediterranean Sea to different characteristics, such as nutrient depletion and low productivity towards the east (Salihoglu et al., 1990), the westward transport and export of organic matter by the underlying deep Mediterranean compensation current (Dugdale and Wilkerson, 1988), and strong grazing of phytoplankton by the high zooplankton standing stock in the upper layers (Weikert and Koppelmann, 1993). The continental slope and bathyal sediments of the eastern Mediterranean have been considered as a separate subsystem (Tselepides et al., 2000a) which is characterised by: a) negligible inputs of primary organic matter, b) organic matter composed mostly of refractory compounds, and c) extremely low concentrations of potentially limiting organic nutrients (e.g. proteins and lipids) that sharply decline with increasing distance from the coast and sediment depth.

Danovaro et al. $(1995,2000)$ found that in the deep eastern Mediterranean, the horizontal and vertical distribution of meiofauna is controlled by food quality (expressed as the percentage of labile versus total sedimentary organic matter), whereas other studies contend that the distribution of meiofaunal communities is directly related to the amount of chloroplastic pigment equivalent (CPE), which is an indicator of the presence of sedimentary phytoplankton detritus, the main food source to deep-sea benthic communities (Pfannkuche et al., 1983; Pfannkuche, 1985; Soetaert et al., 1991a). Boetius et al. (1996) found that in the eastern Mediterranean concentrations of CPE decrease from 4-6 $\mu \mathrm{g} \mathrm{cm}^{-2}$ on the continental shelf to $0.1-1 \mu \mathrm{g} \mathrm{cm}^{-2}$ at abyssal depths. However, strikingly high concentrations ( > $10 \mu \mathrm{g} \mathrm{cm}^{-2}$ ) were measured in the Hellenic and Pliny Trenches (where depths exceed $3750 \mathrm{~m}$ ), supporting the hypothesis that deep-sea depressions tend to accumulate organic material and are therefore characterised as "hot spots".

Quantitative and qualitative information on the ecology of meiofauna from trench areas worldwide is limited to only a few published papers on the Puerto Rico Trench (George and Higgins, 1979; Tietjen et al., 1989), the Philippine Trench (Thiel, 1979a), the Ogasawara Trench (Shirayama, 1984), the Japan Trench (Shirayama and Kojima, 1994) and the Atacama Trench (Danovaro et al., 2002). Most of these studies were undertaken along bathymetric transects and attempted to relate meiofaunal abundances and biomasses to surface primary production or to surface derived organic matter. Overall, a general decrease in abundance and biomass of metazoan meiofauna with food availability is now well established (De Bovée et al., 1990; Tietjen, 1992; Vincx et al., 1994), thus indicating a clear relationship between meiofauna distribution and food supply (Sibuet et al., 1989; Vincx et al., 1994; Danovaro et al., 2000).

Tselepides and Lampadariou (2004) conducted an extensive investigation of the bathyal and abyssal meiofauna of the deep Ionian and Levantine Seas in the eastern Mediterranean. They present a comprehensive data set on meiofaunal distribution in rela- 


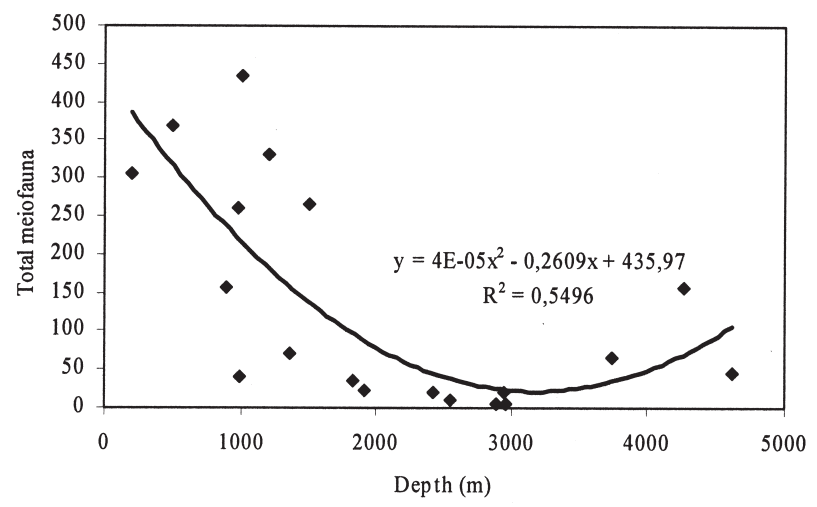

FIG. 3. - Regression of total meiofaunal abundances (ind. $10 \mathrm{~cm}^{-2}$ ) from 195 to $4617 \mathrm{~m}$ depth in the eastern Mediterranean (from Tselepides and Lampadariou, 2004).

tion to depth and a suite of sedimentary environmental parameters, which were used as indicators of food availability. The results indicate a strong dependence of meiofaunal abundance on depth (Fig. 3 ), distance from the coast and labile sources of organic carbon such as proteins and lipids. The Pliny and Hellenic trenches were also sampled and found to function as traps of organic matter supporting comparatively similar meiofaunal abundances to those occurring at shallower depths, and microbial activity potentials that exceeded those at the abyssal plain by an order of magnitude (Boetius et al., 1996). Although most of the meiofaunal components were found not to respond dramatically to the influx of fresh phytodetrital material, the fact that their values were relatively similar to those found at shallower depths plus the drastic increase in harpacticoid copepods together with the enhanced microbial activities partially justified the characterisation of the eastern Mediterranean trenches as "benthic hot spots". The results of this study present a deviation from what is considered as normal. It seems that the ultra oligotrophic deep Mediterranean environment occasionally undergoes periods of increased food availability, which can be related to events occurring further up in the water column. Such an event was the eastern Mediterranean "Transient", which was triggered by a combination of atmospheric, meteorological and hydrological factors (Roether et al., 1996).

It seems that this event had a pronounced effect on the entire ecosystem. The enhancement in benthic activity recorded in the trenches of the eastern Mediterranean may well have been the indirect result of a basin-scale uplifting of nutrient-rich deep waters into the euphotic zone. The latter phenomenon was followed by an increase in biological pro- ductivity, vertical fluxes and POM propagation to the deep sea through cascading, down-slope sliding and entrapment of organic rich sediments into the Hellenic and Pliny trenches.

Recenty, Danovaro et al. (2004), attempt to relate climate change to nematode diversity in the deep eastern Mediterranean. By using a decadal data set (1989-1998) they provide evidence that deep-sea nematode diversity can be strongly and rapidly affected by temperature shifts.

\section{Benthic response to particulate fluxes}

In a thorough review regarding benthic response to particulate fluxes, Danovaro et al. (1999) gave a very comprehensive comparison of particle fluxes, sedimentary OM composition, and microbial and meiofaunal parameters. They used quantitative data from various stations in the Gulf of Lions and Catalan Sea (northwestern Mediterranean), as well as from the Cretan Sea (eastern Mediterranean). Benthic responses in relation to the different trophic conditions prevailing in the two areas were compared in terms of: (1) temporal and spatial variability of the mass fluxes; (2) pelagic-benthic coupling in organic matter composition (such as proteins, lipids, soluble carbohydrates and CPE); (3) microbial response to changes in organic matter composition and POC fluxes; (4) meiofaunal response to changes in organic matter composition and particle fluxes; and (5) relative significance of bacteria and meiofauna. Mass fluxes at equal depths were found to be up to two orders of magnitude higher in the western than in the eastern Mediterranean. Clear seasonal changes were reported in both areas, although mass fluxes and variability were consistently higher in the northwestern Mediterranean. From primary production estimates in the western and eastern Mediterranean (140-160 vs. $\approx 19-60 \mathrm{mgC} \mathrm{m}^{-2} \mathrm{~d}^{-1}$ respectively), it was calculated that a carbon export from the euphotic layer to $1000 \mathrm{~m}$ depth is equivalent to about $10 \%$ in the Gulf of Lions and 2-3\% in the Cre$\tan$ Sea. Chlorophyll- $a$ concentrations at similar depths were 2-3 times higher in the western basin. Carbohydrates were the dominant biochemical component in the Cretan Sea sediments, while total amino acids represented an important fraction of the biodegradable material in the Gulf of Lions-Catalan Sea. In the western Mediterranean, bacterial densities (annual mean $7.9 \times 10^{8}$ cell g-1) were about 4 times higher than in the Cretan Sea (annual mean $2.1 \times 10^{8}$ cell $\mathrm{g}^{-1}$ ), indicating that in deep-sea sedi- 
ments different trophic conditions influence bacterial densities. Meiofaunal abundance and biomass were similar on the continental shelves of the two areas (940-2558 ind. $10 \mathrm{~cm}^{-2}$ ) but at bathyal depths densities in the Cretan Sea (range: 60-120 ind. 10 $\mathrm{cm}^{-2}$ ) were 4-25 times lower than those in the northwestern Mediterranean (500-1500 ind. $10 \mathrm{~cm}^{-2}$ ). In contrast to what was observed in the northwestern Mediterranean, deep-sea meiofaunal assemblages of the Cretan Sea did not react (in terms of density or biomass) to the seasonal variations in food inputs. Here, the bacterial to meiofaunal biomass ratio displayed much higher values (up to $>20$ ), possibly causing competition for food sources with small metazoans. The efficiency with which the POC fluxes were being exploited was estimated. In the northwestern Mediterranean about $0.14 \mathrm{mgC} \mathrm{d}^{-1}$ are available to each meiofaunal individual compared to the $0.07 \mathrm{mgC}$ ind. ${ }^{-1}$ in the eastern Mediterranean. Similarly, $3.3 \mathrm{mgC}$ were provided daily per $1 \mathrm{mgC}$ of bacterial biomass in the western Mediterranean, compared to 0.07 in the eastern Mediterranean. These data indicate that the benthic components in the Cretan Sea, and in the eastern Mediterranean in general, are subject to more limiting trophic conditions, and therefore might have a higher efficiency at exploiting particulate organic fluxes.

\section{Concluding remarks}

The deep-sea floor has traditionally been considered as a stable unchanging environment inhabited by sparsely distributed organisms that depend upon a constant supply of fine (mostly refractory) particles settling from the euphotic zone. This contention was also considered to be true for the Mediterranean Sea, which at the turn of the 20th century was even considered to be "azoic".

However, during the past three decades, new technological developments, sampling gear and environmental monitoring methods in concert with a proliferation of multidisciplinary research programs have gradually changed this notion. We now know that the deep Mediterranean Sea is a dynamic environment linked to upper water column processes through the varying (in both space and time) influx of organic matter. It is also driven and characterised by the dynamics of major geomorphological features (deep abyssal basins, the Mediterranean ridge system, anoxic hypersaline abyssal basins, mud volcanoes, cold and hydrothermal seepage, seamounts, submarine canyons, the Nile deep-sea fan, etc.) which are encountered in specific areas, and to a large extent in the eastern Mediterranean.

The benthic community has been shown to react very rapidly to seasonal or/and episodic sedimentation of organic matter. Small size fractions of benthic organisms (bacteria and protozoa) are known to respond to such inputs, even when the quality and quantity of the sedimenting matter is low or poor. The main processes therefore controlling pelagicbenthic coupling are primarily the export flux of organic matter from the euphotic zone, the quantity and quality of the OM arriving on the seabed and of course its rate of oxidation and mineralisation.

In addition to the above, the deep eastern Mediterranean also seems to be governed by cataclysmic events that alter the entire biogeochemical balance of the seabed. These events are either the end result of a combination of climatic factors and/or local reactions to a suite of hydrological "perturbations" which cause uplifting of nutrient rich deep-waters into the euphotic zone and therefore enhance biological productivity and OM flux to the seabed. The large deep water transient in the eastern Mediterranean is now considered a classic example of how a "deep-sea desert" can relatively abruptly be converted into an "oasis" or a monoculture of certain opportunistic species (e.g. the polychaete Myriochele fragilis). Species such as Chaceon mediterraneus, which were once only known from the western Mediterranean basin are now found everywhere and in high numbers even in the deep eastern basin. The questions thus arising are whether the deep-sea ecosystem responds to climate change, and whether this is also evident in the oligotrophic eastern Mediterranean. The answer to these "ambitious" or "provocative" questions is yes. There is accumulating evidence that climate change has caused an immediate accumulation of organic matter on the deep-sea floor, altered the carbon and nitrogen cycles and affected benthic activity in general. Investigations undertaken in the deep eastern Mediterranean during the past 15 years have revealed that it is occasionally a very dynamic environment responding to major climatic or hydrological changes or forcings by altering its biogeochemistry and concomitantly its benthic community structure.

Recently, large changes in the physico-chemical characteristics of the eastern Mediterranean deep water, known as the "transient event", have been reported (Roether et al., 1996). Long-term investigations of deep-sea biology have been carried out in the eastern Mediterranean, providing a unique opportunity to study the response of a deep-sea 
ecosystem to climate variability on a decadal scale. Because the Mediterranean Sea behaves as a miniature ocean (Bethoux et al., 1999), changes that occur in the eastern Mediterranean can be used as a model of the potential instability of the oceanic circulation. Such a model would help our understanding and our predictions of the impact of climate change in deep seas worldwide (Lascaratos et al., 1999). Indeed, Danovaro et al. (2001), report that in the past decade, extensive climate change has modified the physico-chemical characteristics of deep waters in the eastern Mediterranean. Climate change has caused an almost immediate accumulation of organic matter on certain areas of the deep-sea floor, altered the carbon and nitrogen cycles and had negative effects on deep-sea bacteria and benthic fauna. They propose a miniature ocean model in an attempt to provide new ways of interpreting signals from the deep sea. Their approach indicates that contrary to what might have been expected, deep-sea ecosystems do respond quickly to climate change.

The deep Mediterranean differs from the betterknown oceanic abyss in terms of its physical environment, food supply and degree of inter-specific interaction (both competition and predator-prey), any of which could influence the physiological characteristics of the fauna present. Influences may be direct (e.g. effects of temperature on metabolism) or, given sufficient time, through selection of advantageous traits. In the case of the deep Mediterranean, has there been sufficient time and selective pressure for adaptation, or are these just cold-water animals surviving in a warm sea?

\section{FISHERY AND FISH ASSEMBLAGES}

\section{Introduction}

The Mediterranean Sea is a semi-enclosed sea characterised by a continental shelf most frequently reduced to a narrow coastal fringe and covering less than $30 \%$ of the total area. The bathyal ground extends for about $60 \%$ of the whole basin, whereas the abyssal plane covers about $13 \%$ of the bottoms. Despite these differences in the extension of the bottom types, most of the Mediterranean living resources are exploited on the continental shelf, where a high variety of species and biocoenoses occur and many fishing techniques and related activities have long been carried out. In spite of the long history of biological resource harvesting in the
Mediterranean coastal areas (Caddy, 1993; Farrugio et al., 1993), the exploitation of deep-sea organisms started only in the first few decades of the last century due to the development of the technology for seeking in deep waters. In particular, the red shrimps Aristaeomorpha foliacea and Aristeus antennatus began to constitute the target of deep-water bottom trawl fishing in the 1930s in the Ligurian Sea, where the first trawlers that sought the epibathyal depths managed to catch between 100 and $200 \mathrm{~kg} \mathrm{~d}^{-1}$, and in some periods, after the second world war, the captures went up to $1000 \mathrm{~kg} \mathrm{~d}^{-1}$ per boat (Relini and Orsi Relini, 1987). Nevertheless, it was not until the middle 1940s when its importance as an exploited resource was evidenced in the Catalan and Balearic seas (Arté, 1952; Bas et al., 1955; Bas, 1960; Massutí, 1961; Maurin, 1965a, b; Relini-Orsi and Relini, 1972; Massutí and Daroca, 1978), and it was pointed out as one of the latest fisheries developed in the Mediterranean.

\section{Western Mediterranean fisheries}

Though fisheries down to a depth of $700 \mathrm{~m}$ have been usual since the middle of the last century in the Mediterranean sea, the deep-sea bottoms down to $1000 \mathrm{~m}$ are still totally pristine. At these depths there are no specialised fisheries as in other parts of the world such as Canada and Australia. However, the trawl bottom fishery currently goes down to almost $1000 \mathrm{~m}$. This deep trawl bottom fishery is carried out due to two fundamental factors. The first one is the narrowness of the shelf, crossed by numerous submarine canyons. This brings the deep depths within a few miles of the coast. The second one is the human density of Mediterranean regions and the high demand for marine products, which are traditional in the Mediterranean diet. These factors generate high competition between fishermen. The Mediterranean sea is considered an oligotrophic sea and is characterised by over-exploitation of its marine resources, this over-exploited situation began in the 1980s. The trawl boats that work on deep-sea grounds have powers of between 300 and $1800 \mathrm{CV}$. Boats of wood or iron have now been replaced by boats of glass-fibre and of a catamaran type with high technologies. However, mixed enterprises to exploit the deep-sea ground of North Africa are now common. The deep-sea rose shrimp, Aristeus antennatus (Risso, 1816) (Crustacea, Decapoda, Dendrobranchiata, Aristeidae), is the most important fishery in the western Mediterranean Sea 
(Sardà and Martín, 1986; Demestre and Lleonart, 1993; Bianchini and Ragonese, 1994; Carbonell et al., 1999). This species is a characteristic component of the demersal muddy bottom community on the middle slope at depths between 400 and $800 \mathrm{~m}$ (Cartes and Sardà, 1993), where Cartes and Sardà (1992) and Maynou and Cartes (2000) have defined it as a nektobenthic species of moderate to high swimming mobility. However, this species is also fished frequently between 400 and $800 \mathrm{~m}$ and in other Mediterranean areas (Bianchini and Regonese, 1994; Carbonell et al., 1999; Papaconstantinou and Kapiris, 2001; Cau et al., 2002). The distribution of this species is nonetheless considerably broader, reaching depths of at least 3300 m (Sardà, 2003), indicating that the species is eurybathic with a distribution that is considerably broader than that of other decapod crustacean species.

The spatio-temporal behavioural pattern of $A$. antennatus is well-known, with the species forming seasonal aggregations on the middle slope at depths between 400 and $900 \mathrm{~m}$. These aggregations form between late winter and early summer (Tobar and Sardà, 1987; Demestre and Martín, 1993; Sardà et $a l .$, 1994). Towards the end of summer the shrimp shoals tend to break up and move inside submarine canyons, with the shrimp being fished at shallower depths along the margins of the canyons (Sardà, 1993; Sardà et al., 1994; Sardà et al., 1997).

Studies carried out on the catchability of shoals of this species (Sardà and Maynou, 1998) have suggested that the shoals take on an elongate shape parallel to the coast between early spring and summer. This is when the shrimp stock bears the brunt of the fishing effort (Tudela et al., 2003; Sardà et al., 2003a), because shoal formation is at its peak on the part of the slope most readily accessible to trawlers, and females attain maximum size, that is, the biomass concentration is also at its peak. In addition, the marketability of this species is also highest at this time (Sardà et al., 2003b).

In the last decade a great number of studies have focused on the estimation of the level of exploitation of A. antennatus populations. Furthermore, different management options have been studied, taking into account biological and fishing aspects, to offer the most appropriate and sustainable fishery (Demestre, 1990; Demestre, 1993; Demestre and Martín, 1993; Carbonell and Alvarez, 1995; Carbonell et al., 1999). Despite fluctuations in landings over the annual series, a clear seasonal periodicity is detected, with increased landings in late winter, spring and early summer. Also, inter-annual fluctuations of around 8 years have been detected (Tobar and Sardà, 1987; Carbonell and Acevedo, 2003). The general trend of all the results shows a situation of the stocks not being overexploited yet, but with a tendency to go far from the optimum exploitation.

The fact that $A$. antennatus appears to be underexploited or near the optimum levels on the Spanish coast, in contrast with the majority of demersal resources, is due to at least two characteristics of this species. Firstly, the whole stock is not available for fishing since only a certain proportion of the stock is accessible to commercial fishing (Demestre and Martín, 1993; Sardà et al., 2003b), and the species has an extremely wide distribution in bathyal waters (Sardà et al., 1997). Secondly, the turnover rate is high. Most demersal resources, particularly fish, have a low turnover rate that makes them "easy victims" to overfishing (Demestre and Lleonart, 1993).

On the lower slope, between 1000 and $3300 \mathrm{~m}$ depth, the density is lower, there is no fishing activity (virgin grounds), the sex proportions are not significantly different from 1:1 (Sardà and Cartes, 1993; Sardà et al., 2003b; Sardà et al., 2004), and no information is available on seasonal population movements at these depths. The study of the life history of Aristeus antennatus presents an interesting scenario: the fishing grounds are mainly occupied by female, large-sized individuals showing a high density, while the virgin grounds are occupied by smaller-sized individuals showing a low density. However, Aristeus antennatus does not seem to be overexploited in its fishing grounds (Demestre and Lleonart, 1993; Tursi et al., 1996; Martínez-Baños, 1997; García-Rodríguez and Esteban, 1999). Thus, considering the present state of knowledge of $A$. antennatus, the questions addressed are about the relationship and interaction between exploited and virgin populations. The grounds below $1000 \mathrm{~m}$ depth are beyond the reach of fishing boats and we can assume that the shrimp populations are virgin at these depths. These virgin populations have lower densities and a higher proportion of males than the exploited populations (Sardà et al., 2003a,b).

As a matter of fact, considering the multi-species nature of the Mediterranean fisheries, deep-water shrimps are caught between 400 and 800 m together with many other species considered by-catch, some of which, such as Norway lobster (Nephrops norvegicus), hake (Merluccius merluccius), angerfish (Lophius spp.) or conger (Conger conger) have 
a high commercial value, while others, such as the greater forkbeard (Phycis blennoides), rockfish (Helicolenus dactylopterus) and the golden shrimp (Plesionika spp.), are less valuable and many others are completely discarded. In the deeper range the main catch families are composed of Moridae (Mora moro) and Alepocephalidae (Alepocephalus rostratus) of large size or Macruridae (Coelorhynchus coelorhynchus, Trachyrhynchus scabrus, Hymenocephalus italicus, Chalinura mediterranea, Nezumia aequalis) of medium size. High biomasses of these species are detected between 900 and $1300 \mathrm{~m}$ (Rucabado et al., 1991; Stefanescu et al., 1992; Morales-Nin et al., 2003; Cartes et al., 2004; Massutí et al., 2004; Moranta, et al., 2004), but no fishery is carried out at the moment at these depths.

\section{Central Mediterranean fisheries}

Deep-water species in the central Mediterranean are mostly exploited by the Italian fleet, which is composed of typical Mediterranean boats and is almost exclusively artisanal in structure, except for some areas (e.g. the Sicilian Channel) where larger trawlers operate on a more industrial scale. Most of the vessels are recorded as multiple-gear vessels and are generally of small gross tonnage and smaller than $12 \mathrm{~m}$ in length (COM, 2002). Most of the trawlers are located in the Sicily Channel and in the South Adriatic Sea. However, in this latter basin deep-water fishing is less important than in the coastal one.

Italian bottom trawlers can share fishing activity throughout the year (in many cases during the same day) both on red shrimps and on shallower species, such as deep-water shrimp (Parapenaeus longirostris), Norway lobster and hake, according to the varying availability of these resources. For this reason, it is difficult to quantify the effective fishing effort targeting specific deep-water species. The proportion of the different species varies largely among the basins. From official national statistics (ISTAT), during the past decade the total Italian landings of "red shrimps" showed an oscillating trend between 3000 and 6000 t. However, apart from the low reliability of these data, several species are grouped within the same commercial category of "red shrimps" (A. antennatus, A. foliacea, P. martia, other pandalids, etc.).

In the central Mediterranean the main fisheries targeting red shrimps are located along the Italian Ionian Sea, where fishing occurs from coastal waters to $700-750 \mathrm{~m}$. Fish, crustaceans and cephalopods make up about 70, 20 and $10 \%$ of the mean catch respectively. Commercial fish and cephalopods are mostly caught on the continental shelf, while crustaceans with a high market value are mainly fished on the slope (between 200 and 400 $\mathrm{m}$ mostly Parapenaeus longirostris; between 400 and $700 \mathrm{~m} \mathrm{~A}$. antennatus and A. foliacea). N. norvegicus is mostly caught on the continental shelf along the Apulian coasts and on the slope along the Calabria (Tursi et al., 1994, 1998). In general, higher activity rates in the red shrimp fishing fleet occur during spring and summer for the following reasons: a) better weather conditions which also encourage small vessels to fish far from the coast on red shrimp fishing bottoms; b) increased commercial demand and average price as a result of the increase in tourists along the coast; and c) the longer duration of the daylight, making it possible to explore more areas if the target species is scarce.

During an EU study project (Sardà, 2001) conducted in the Gallipoli fishery, it was shown that the fishing on the red shrimps was carried out by $45.8 \%$ of the trawlers. On average, the contribution of red shrimps made up $58.6 \%$ in weight and $66.15 \%$ in economic value of the total catch (Carlucci et al., in press).

The exploitation of both species progressively decreased until the collapse of the stocks in the late 1970s. While a recovery of $A$. antennatus stock was shown in 1985, which led to a restart of the fishing activity (Orsi Relini and Relini, 1988), the presence of A. foliacea in the area is currently extremely scarce and insignificant in commercial terms (Fiorentino et al., 1998). Overfishing together with environmental decay, hydrology, failure of recruitment and parasitic attack of stressed stock were considered as the possible causes of the stock collapse (Orsi Relini and Relini, 1985; Relini and Orsi Relini, 1987).

Nowadays, thousand of tons of these species are landed along the Mediterranean coasts of the western and central basin (Relini et al., 1999; Demestre and Martín, 1993; Tudela et al., 2003; Carbonell et al., 1999; García-Rodríguez, 2003). Red shrimp fisheries are often distinct even if a degree of overlapping exists: the main $A$. foliacea fisheries are located in the Strait of Sicily and in Southern Sardinia, whereas A. antennatus is mostly caught in the western Mediterranean and in the Ionian Sea (Fig. 4), west-east and north-south gradients (Bianchini and Ragonese, 1994; Cau et al., 2002; Sardà et al., 2001). 


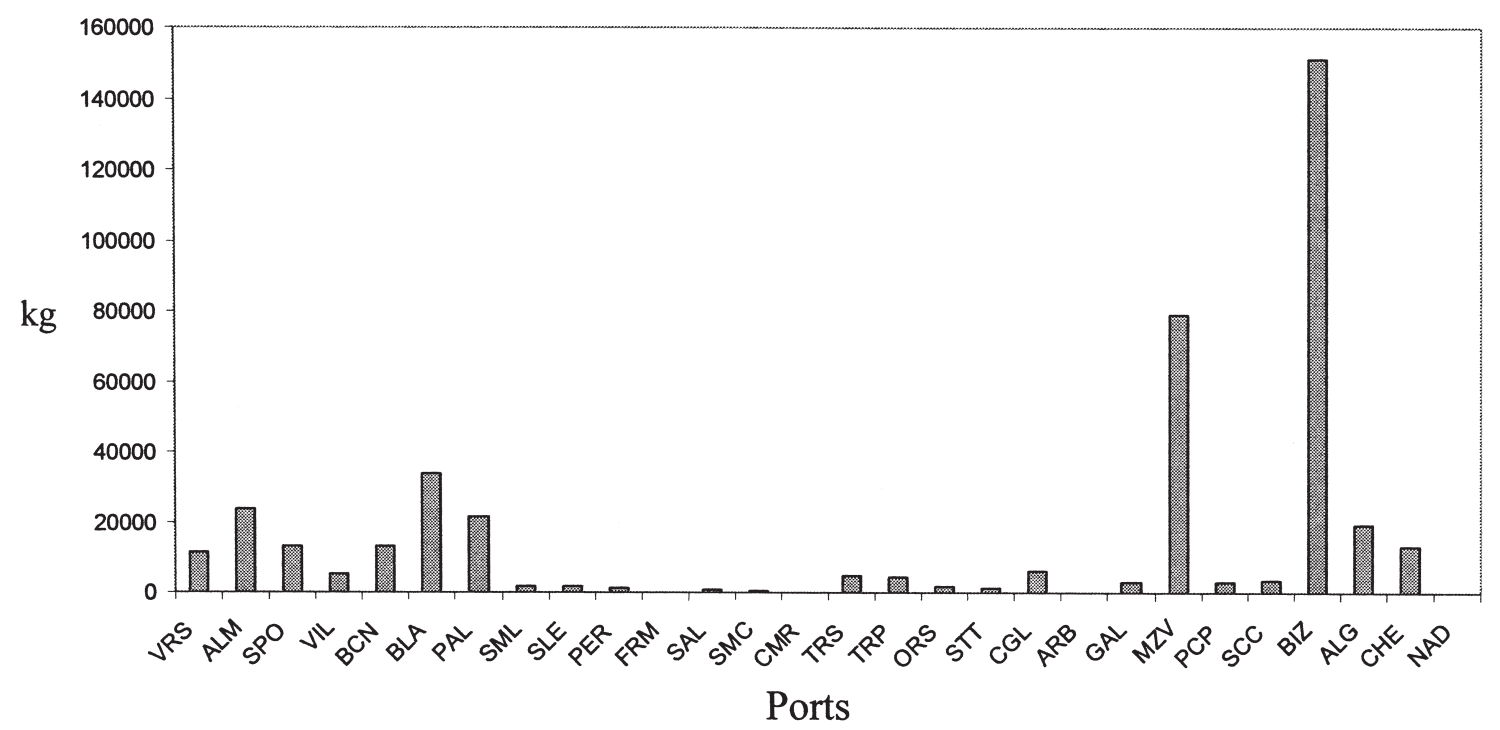

FIG. 4. - Deep-sea shrimp landings (Aristeus antennatus + Aristaeomorpha foliacea) by different ports in the western Mediterranean (VRS, Villareal; ALM, Almeria; SPO, Sta. Pola; VIL, Vila Joiosa; BCN, Barcelona, BLA, Blanes; PAL, Palma; SML, Sta. Margarita; SLE, Sestri; PER, Porto Ercole; FRM, Formia; SAL, Salerno; SMC, Sta. Maria; CMR, Marina di Camerota; TRS, Terrasini; TRP, Trapani; ORS, Oristano; STT, Sant'Antioco; CGL, Cagliari; ARB, Arbatex; GAL, Gallipoli; MZV, Mazara; PCP, Portopalo; SCC, Sciacca; BIZ, Bizerte; ALG, Algiers; CHE, Cherchell; NAD, Nador); from Sardà (2001).

The deep-water shrimps A. foliacea and A. antennatus show a similar depth distribution pattern on the two sides of the Ionian Sea, with the former species in shallower waters than the latter. However, their relative abundance changes between Italian and Greek waters. A. foliacea is far more abundant than A. antennatus off Greece, while this latter species shows a higher density in Italian waters than in Greek ones. This could be related to the different water masses on the slope of the Ionian basin, which along the Greek coasts are warmer and have a higher salinity, while along the Italian ones they are colder and less saline (Robinson and Golnaraghi, 1992; Theocaris et al., 1993, Rabitti et al., 1994). A. foliacea would be mainly linked to the former, whereas A. antennatus would be mainly linked to the latter, according to Ghidalia and Bourgois (1961) and Bombace (1975). Although the hydrographic hypothesis of Ghidalia and Bourgois (1961) needs to be confirmed, the Mediterranean distribution of the two species would seem to support it (Relini and Orsi Relini, 1987; Murenu et al., 1994; Ragonese, 1995). However, there are no studies that have established other specific hypotheses on the different distribution of these two companion species.

A study on the selectivity of the otter trawl was carried out by Colloca et al. (1998) in the central Tyrrhenian Sea. For a mesh size of $16-18 \mathrm{~mm}$, the length of first capture ranged between 24 and 31.6 $\mathrm{mm}$, while for a mesh size of $20-22 \mathrm{~mm} C L$ was comprised between 31.5 and $38.6 \mathrm{~mm}$. In the south- ern Tyrrhenian Sea the size at first capture and the respective age was calculated by the selection ogive for a $32 \mathrm{~mm}$ stretched mesh size (Spedicato et al., 1995): $\mathrm{L} 50=32.76 \mathrm{~mm} \mathrm{CL}$ and $\mathrm{T} 50=0.9778$. Ragonese et al. (1994) in the Sicily channel carried out some studies of selectivity and suggested a mesh size of up to $28 \mathrm{~mm}$ side to reduce the juveniles in the catches.

A. antennatus seems to support a sustainable fishery along the Italian coasts despite the high fishing pressure. This might be due to the very wide depth distribution in bathyal waters and to the fact that part of the population is not vulnerable to trawling (Sardà, 1993). Another reason could be the high fecundity of this species. On the other hand, A. foliacea exhibits a marked overexploitation due to its greater vulnerability to fishing, since both juvenile and adult $A$. foliacea are almost exclusively distributed at depths at which bottom trawling occurs (Matarrese et al., 1997; D’Onghia et al., 1998a).

In the Italian Ionian Sea there are some other local small-scale fisheries using longline and targeting hake and other deep-sea species such as rockfish, greater forkbeard and bluntnose sixgill shark (Hexanchus griseus). Another small-scale fishery is that targeting Hexanchus griseus, which is carried out with longlines in the central and southern Aegean Sea at depths of 600 to $1500 \mathrm{~m}$. The species has a low commercial value, but the catch is quite high and the fishery is profitable. The length of the longlines is about $15-20 \mathrm{~km}$. The duration of each 
trip is $1-5$ days. The fishery is carried out throughout the year. The catch consists of large specimens (100-200 k each one). The daily catch could be 1000 k. By-catch species are mainly Conger conger and Squalus spp. (Stergiou et al., 1996, 1997). However, these species have a negligible importance compared to those caught by deep-water bottom trawling. Longliners are mainly distributed in the southern Adriatic fishing hake as target species between 200 and $400 \mathrm{~m}$ (De Zio et al., 1998).

The trawl fishing activities in the Greek Ionian Sea do not generally exceed $400-500 \mathrm{~m}$ in depth. The most commercially important species within this depth range are Merluccius merluccius, Mullus barbatus, Mullus surmuletus, Lophius spp, Micromesistius poutassou, Parapenaeus longirostris and Illex coindetii. In deeper waters, fishing activities are limited and related mainly to the fishery of hake and wreck fish (Polyprion americanus) with longlines, fishery of hake in summer with nets and fishery of bluefin tuna and swordfish with surface lines (Papaconstantinou and Stergiou, 1995; Stergiou et al., 1997). The fishery in deeper waters is limited (1) because of the inexperience of the fishers with working at these depths, (2) because the fishers do not know that there are important commercial stocks at these depths, and (3) because the price of the deep-water resources in the market is until now very low. Thus, the fishery in the Greek Ionian Sea is limited to the continental shelf, the surface of which is very narrow. Some Italian bottom trawlers are working in the international waters close to the Greek coasts of the Ionian Sea, especially during summer when the weather is better and when the Greek trawlers are not working. Target species at depths of 400 to $800 \mathrm{~m}$ are A. antennatus, A. foliacea, $N$. norvegicus, $M$. merluccius, $M$. poutassou, T. lyra, H. dactylopterus and Scorpaena spp. The contribution of the two red shrimps in the total catch during sampling in the deep water project at depths of $300-500 \mathrm{~m}$ was $6 \%$ and at depths of $500-750 \mathrm{~m} \mathrm{30 \%}$. A common conclusion of the research project that has been carried out so far is that A. foliacea is more abundant than A. antennatus (Mytilineou and Politou, 1997; Politou et al., 2003; Papaconstantinou and Kapiris, 2003). The discovery of new fishing resources in the deep waters of the Greek Ionian Sea is very important. As a result, the area in which the fishing effort is exercised will be extended and the production will increase. The already known biological resources could be less exploited and new socio-economic perspectives for the inhabitants will arise (Papaconstantinou and Kapiris, 2001, 2003).

\section{The Deep-sea biocenosis}

Among the habitats affected by the deep-water fisheries in the Mediterranean, the biocenosis of the bathyal mud is the most widespread and two facies can be distinguished: a) that of the viscous mud with a very fluid superficial layer characterised by the big sea pen Funiculina quadrangularis and the crustaceans Parapenaeus longirostris and Nephrops norvegicus; $b$ ) that of firm and compact muds characterised by the cnidarian species Isidella elongata and Actinauge richardi, the crustaceans Aristeus antennatus, Aristaeomorpha foliacea, Plesionika edwardsi, Plesionika martia, Munida intermedia, and the cephalopods Sepietta oweniana, Neorossia caroli and Pteroctopus tetracirrus. Within these two facies the strictly benthic species Funiculina quadrangularis and Isidella elongata have almost completely disappeared from the trawlable bottoms of the most Mediterranean areas, except in a few limited zones (e.g. Malta bottoms).

The western Mediterranean is characterised by a narrow and sinuous shelf grooved by deep submarine canyons and channels between islands frequently reaching more than $1500 \mathrm{~m}$ depth. The muddy substratum is affected by frequent slide processes near the margins of canyons. These structures support different species of fish and invertebrates with life cycles adapted to space-temporal processes linked to these geomorphological structures. Due to the frequent trawling in these regions, no specific biocenosis can be defined. However, when experimental hauls are performed in virgin grounds, Issidella elongata appears in high quantities. The same species named in the previous paragraphs are also found at this depth.

On the bathyal ground of the northern Ionian Sea a broad biocenosis of white-corals has been identified at depths between 450 and $1100 \mathrm{~m}$ (Mastrototaro et al., 2002; Tursi et al., 2004). Living colonies of the branched species Madrepora oculata and Lophelia pertusa with the solitary species Desmophyllum cristagalli were found. The calcareous clumps are made up of white and living branches at the top and dead darkened corals at the base. The epibiotic fauna is dominated by sponges, bivalves and polychaete worms. This biocenosis, which provides refuges for marine fauna, is vulnerable to the 
otter board of the trawl net and also represents a deterrent for this kind of fishing gear, since the net might get entangled in it. Moreover, deep bottom gillnets and traps, sometimes employed in this area, might get entangled in the coral branches and act as "ghost fishing". This kind of biocenosis is also present in other areas such as the Sicilian Channel and the South Adriatic and in other Mediterranean areas.

Deep-water shrimp fishing grounds are located around the biocenosis of white-corals as well as on the margin of submarine canyons in the western Mediterranean, areas which can act as recruiting grounds and reservoirs of mature specimens also for other deep-water species, such as hake and rockfish. These specimens escape trawl fisheries, reach maturity and renew the exploited portion of the stock annually, sustaining the recruitment under conditions of high fishing mortality on the immature age groups (the spawning refugia paradigm of the Mediterranean fisheries) (Caddy, 1993).

Studies of the effects of fishing on marine deep ecosystems in the Mediterranean Sea have mostly addressed the population structure and dynamics of target species, while little is known of the impact of fishing on benthic communities, non-target species and biodiversity. Discard studies indicate that during the deep-water trawling in the Ionian Sea the discarded catch represented an large fraction of the total catch $(20-50 \%)$. This is almost exclusively due to unwanted fish species, while discards of the target species and other commercial ones are negligible. Discard rates seem to increase with the total catch and depth. The unwanted species are mostly represented by Galeus melastomus, Hoplostethus mediterraneus and the species of the Macrouridae family (Trachyrhynchus scabrus) (D’Onghia et al., 2003a).

\section{Fish assemblages and ecology}

A number of authors have described the composition of the community supporting the fishery of the deep-sea rose shrimp, Aristeus antennatus, in the western Mediterranean Sea separately for crustaceans and for fish (Abelló et al., 1988; Stefanescu et al., 1992; Cartes and Sardà, 1993; Stefanescu et al., 1992, 1993 and 1994). This community, dwelling over muddy bottoms on the middle slope, is composed principally of the target species, Aristeus antennatus, along with other species of no commercial interest, e.g. Geryon longipes, Poly- cheles typhlops, Lepidion lepidion, Alepochephalus rostratus and Trachyrhynchus scabrus. A. antennatus is an interesting species as compared to the other species dwelling in the community because of certain specific biological characteristics, namely: (1) its broad depth distribution, making it a highly eurybathic species, and (2) though fishing pressure has been extremely high over the past 40 years, the population seems to be in a healthy state of exploitation. Cartes and Sardà (1993) defined three main zonations for the deep-sea decapod fauna in the western Mediterranean: the upper middle slope above $670 \mathrm{~m}$; the lower middle slope between 850 and $1200 \mathrm{~m}$; and below this last-mentioned depth, a transition zone to the lower slope community (down to $2000 \mathrm{~m}$ ). The above-mentioned boundaries represent genuine barriers to distribution for several decapod crustacean and fish species, but not for A. antennatus, which enjoys a continuous distribution between 550 and to at least 3000 m (Sardà et al., 1993; Sardà, 2001). However, we must consider here that the definition of boundary is a controversial question, often depending on the sampling adequacy and the data employed in the analysis. Koslow (1993), Haedrich and Merrett (1990), Stefanescu et al. (1993), Cartes and Sardà (1993) and Moranta et al. (1998) provided different results investigating in the same areas, but only fishes are considered in these studies. In this paper we present clusters including crustaceans and fishes, reaching similar results as Morales-Nin et al. (2003) with a first boundary around $800 \mathrm{~m}$ depth .

The community boundary at around $900 \mathrm{~m}$ described here is mainly the result of the upper limit to the depth distribution range for such species as Alepocephalus rostratus, Lepidion lepidion, Nezumia aequalis, Acanthephyra eximia and Geryon longipes, species with high abundance and biomass levels. At the present time no technical constraints prevent fishing operations at deeper depths, yet fishermen seem to be aware that there is a community boundary at that level and thus do not operate at deeper depths, in the knowledge that yields of $A$. antennatus there will be insufficient.

This mobility pattern indicates the ability of deep-water shrimp to adapt their life cycle to the structure of canyons on the Catalan Coast (Sardà et al., 2003a,b; 2004). Tursi et al. (1996) found similar population structures in the Gulf of Taranto, where submarine canyons are also an important feature of the geomorphological structure. The most active part, regarding particle sedimentation fluxes, are the 
canyon heads, where smaller individuals concentrate and where food resources would be enhanced due to the autumn plankton bloom and the materials carried downwards from shallower areas influenced by river outflows in this season. The higher activity of submarine canyons in the northwestern Mediterranean has been pointed out by Courp and Monaco (1990) in the Lacaze-Duthiers Canyon (to the north of Catalonia) and for our study region by Puig and Palanques (1998a,b). Furthermore, the influence of episodic fluxes on the behaviour of benthic species in the Mediterranean has been shown by Buscail et al. (1990), De Bovée (1990), Féral et al. (1990), Cartes et al. (2002) and Puig et al. (2001). New evidence on benthic-pelagic coupling and the relationship with particular benthic compartments such as bacteria, meiobenthos and macrobenthos has appeared recently (Angel and Smith, 2000). Company et al. (2001) showed the link between the population structure of different shrimp species in the genus Plesionika Bate, 1888, such as the presence of mature females and recruitment, and the presence of nepheloid layers at different depths. However, the relationship between the geomorphological structure and environment of canyons and the exploited natural resources has not yet been demonstrated in situ as a cause-effect, and the results in this work are a case in this direction. Some aspects are not entirely clear yet. For instance, there is no hypothesis yet as to why females undergoing gonadal maturity would concentrate primarily on the middle and lower slope in spring and summer or why smaller sizes concentrate at canyon heads. Eco-physiological studies are needed in order to clarify the possible relationship between particle fluxes and different population structures of deep-water shrimp in relation to submarine canyons.

Cartes and Sardà (1989) and Maynou and Cartes $(1997,1998)$ consider this species to occupy one of the lower positions in the benthopelagic food chain but to be atypical among deep-sea decapod crustaceans in that it exhibits a relatively high proportion of full stomachs as compared to other deep-sea decapod crustaceans. The high metabolic and growth rate demonstrated for this species by Company and Sardà $(1998,2000)$ is likewise indicative of this. Furthermore, more mobile species tend to have higher metabolic rates, that is, they have higher energy requirements, which translates into a higher daily ration (Koslow, 1996). Given the reduction in food sources in deep-sea habitats, causing dietary overlap and competition for food (Gage and Tyler,
1990), it seems reasonable to assume that A. antennatus will have specific nutritional requirements during spawning and will therefore tend to adopt a distribution at optimum depths to fulfil those requirements. This could be one of the main reasons for the high level of dominance found for this species in the depth interval studied. In the Catalan Sea total consumption by bathyal decapod crustacean assemblages is higher on the upper middle slope $(400-900 \mathrm{~m})$ than on the lower middle slope (900-1200 m). The generally lower food consumption by decapod crustaceans with depth is consistent with the commonly accepted notion that food availability also declines with depth, which holds both for the suprabenthos (one of the main sources of food for benthic decapod crustaceans) and for mesopelagic decapods and euphausiid crustaceans and other crustacean taxa (Carpine, 1970; Cartes, 1998; Cartes and Maynou, 1998; Mura et al., 1998; Carrassón and Cartes, 2002). The reduction in food resources takes place around the zonation boundary located at $900 \mathrm{~m}$, with deep-water rose shrimp shoals being located above that depth.

A comparison of trophic level results with previous studies in shallower waters shows that there are some differences between shallower and deep-sea species (Cartes et al., 2001; Cartes and Carrassón, 2004; Cartes et al., 2004b; Sardà et al., 2004b). Trophic levels of crustaceans from deep-sea area are higher than those obtained from ecological models of the shelf and upper slope area of South Catalan Sea and the coastal area of the Bay of Calvi, Corsica (northwestern Mediterranean Sea). Trophic levels of deep-sea fishes are also in the high range of values compared with the results from shallower areas mentioned above. However, this result cannot be aligned with a viable economical and ecological development of a deep-sea fishery, because the highest trophic levels have been identified to correspond to species with low fecundity and a low metabolic rate. Moreover, the food web structure is composed of highly-specialised organisms and displays low web-like features.

Temperature did not appear to be a determining factor in these processes, the temperature in the Mediterranean being constant at around $13 \pm 0.5^{\circ} \mathrm{C}$ below $200 \mathrm{~m}$ (Hopkins, 1985), so the population structure and behaviour of $A$. antennatus can be considered temperature-independent. In the deep-water habitat that concerns us here, food availability in the deep-sea food web would seem to be the main limiting factor (Gage and Tyler, 1990). 


\section{Management, perspectives and final comments}

There is no specific regulation for deep-water fisheries in the central Mediterranean. For the trawl fishery, other technical measures, such as the codend mesh size $(40 \mathrm{~mm}$ stretched, Ragonese and Bianchini, 1996; Bianchinni et al., 1998; Ragonese et al., 2001), are also in force and other effort restrictions are adopted in the various countries, such as the 45-day closed period in Italy and the four-month closed season (from June to September) in Greece.

No precautionary reference points have been defined until now for the deep-water shrimps A. foliacea and A. antennatus. An increase in the size at first capture and a closed season during spring-summer are recommended in order to reduce fishing pressure on juveniles. The introduction of a larger mesh size than the present one (40 $\mathrm{mm}$ stretched) would appear to be feasible as part of the regulation of an almost mono-specific fishery targeting deep-water shrimps on the slope. Systematic studies on this demersal resource are mostly carried out as part of national research programs, such as GRUND for the Italian waters (Relini, 1998), and the international trawl surveys MEDITS (Bertrand et al., 2002) and COCTEL or DESEAS (Sardà et al., 2001, 2003).

We agree with the comments made by Merrett and Haedrich (1997) regarding the questions of whether the system would be capable of supporting the fishery as a top predator, how the system responds to the new predator pressure and whether this already highly adapted system has the capacity to adapt further.

The main authors of this book also agree that the deep-sea megafauna follow the $K$ ecological strategy in the more abundant and possible commercial species. Moreover, the main species studied concentrate the ovigerous females in the deepest grounds of their distribution range. The low fecundity and the low metabolic rates in a more stable environment represent a high vulnerability of these populations. According with Kostlow et al. (2000), most deepwater stocks are today overfished or even depleted. Depletion of species from deep-sea environments that dominate mid- to upper trophic levels may have long-term ecological implications, but the risk of reducing stock size and age structure to population viability, the potential for species replacement, and the impacts on prey and predator populations are not generally known. However, trawl fisheries have been shown to have potentially severe impacts on the benthic fauna of seamounts where these fish aggregate. The deep-sea fauna, with a high level of endemism, suggests limited reproductive dispersal. The ability of the benthic community to recover following its removal by trawling is not known.

Thus, considering these ecological characteristics, the failure of management of shallower fisheries and the Precautionary Principle with regard to the lack of knowledge of these deep ecosystems, we recommend no commercial exploitation of depths below $1000 \mathrm{~m}$.

\section{REFERENCES}

Abelló, P., F. Valladares, A. Castellón. - 1988. Analysis of the structure of decapod crustacean assemblages off the Catalan coast (North-West Mediterranean). Mar. Biol., 98: 39-49.

Acosta, J., M. Canals, J. López-Martínez, A. Muñóz, P. Herranz, R. Urgeles, C. Palomo and J.L. Casamor. - 2002. The Balearic Promontory geomorphology (western Mediterranean): morphostructure and active processes. Geomorphology, 49: 177204.

Aloïsi, J-C. - 1986. Sur un modèle de sédimentation deltaïque. Contribution à la connaissance des marges passives. Thèse de Doctorat d'Etat. Université de Perpignan.

Aloïsi, J-C., J-P. Chambón, J. Carbone, G. Cauwet, C. Millot, A. Monaco and H. Pauc. - 1982. Origine et rôle du nephéloïde profond dans le transfert des particules au milieu marin. Application au golfe du Lion. Oceanol. Acta, 5: 481-491.

Aloïsi, J-C., C. Millot, H. Pauc and A. Monaco. - 1979. Dynamique des suspensions et mécanismes sédimentogénétiques sur le plateau continentale du Golfe du Lion. C. R. Acad. Sci. Paris, 289: 879-882.

Aloïsi, J.C. and A. Monaco. - 1975. La sédimentation infralittorale. Les prodeltas nord-méditerranéens. C. R. Acad. Sci. Paris, 280 : 2833-2836.

Aloïsi, J.C. and A. Monaco. - 1980. Etude des structures sédimentaires dans les milieux deltaïques (Rhône). Apport à la connaissance des conditions de sédimentation et diagenèse. C. R. Acad. Sci. Paris, 290: 159-162.

Angel, M.V. and R.L. Smith (eds.). - 2000. Pelagic-benthic coupling in the oligotrophic cretan sea. Progr. Oceanogr., 46(2-4): $1-480$.

Arté, P. - 1952. Datos biológicos sobre Aristeus antennatus Risso del "Sot de la Gamba" de blanes (Crustácea, Macrura, Natantia). Publ. Inst. Biol. Apl., X: 145-149.

Astraldi, M. and G.P. Gasparini. - 1992. The seasonal characteristics of the circulation in the north Mediterranean Basin and their relationship with the atmospheric-climatic conditions. J. Geophys. Res., 97: 9531-9540.

Astraldi, M., G.P. Gasparini, L. Gervasio and E. Salusti. - 2001. Dense water dynamics along the Strait of Sicily (Mediterranean Sea). J. Phys. Oc., 31: 3457-3475.

Astraldi, M., G.P. Gasparini, A. Vetrano and S. Vignudelli. - 2002. Hydrographic characteristics and interannual variability of water masses in the central Mediterranean: A sensitivity test for long-term changes in the Mediterranean Sea. Deep-Sea Res., 49: 661-680.

Azov, Y. - 1986. Seasonal patterns of phytoplankton productivity and abundance in nearshore oligotrophic waters of the Levant Basin (Mediterranean). J. Plankton Res., 8: 41-53.

Bacescu, M. -1985 . The effects of the geological and physiological factors on the distribution of marine plants and animals in the Mediterranean. In: M. Moraitou-Apostolopoulou and V. Kiortsis (eds.), Mediterranean Marine Ecosystems, NATO Conference Series, 8, Plenum Press, New York.

Barrier, P., Di Geronimo, Ch. Montenat, M. Roux and H. Zibrowius. - 1989. Presence de faunes bathyales Atlantiques dans le Pliocene et le Plistocene de Méditerranée (Detroit de Messine, Italie). Bull. Soc. Geol. France, 8(4): 787-796. 
Bas, C. - 1965. La gamba rosada (Aristeus antennatus). Publ. Téc. Junta Est. Pesca, 5: 143-155.

Bellaiche, G., L. Droz, J-C. Aloïsi, H. Got, and A. Monaco. - 1980. Eventail sous-marin profond du Rhône: carte bathymétrique au 1/250000. Vie Millieu, 30: 11-13.

Ben-Eliahu, M.N. and D. Fiege. - 1996. Serpulid tube worms (Annelida: Polychaeta) of the Central and Eastern Mediterranean with particular attention to the Levant Sea. Sencken. Marit., 28: 1-52.

Benzohra, M. and C. Millot. - 1995. Characteristics and circulation of the surface and intermediate water masses off Algeria. DeepSea Res., 42(10): 1803-1830.

Berman, T., D.W. Townsand, S.Z. El-Sayed, C.C. Trees and Y. Azov. - 1984. Optical transparency, chlorophyll and primary productivity in the Eastern Mediterranean near the Israeli coast. Oceanol. Acta, 7: 367-372.

Berné, S. - 2002. Carte morpho-bathymétrique du Golfe du Lion au 1/100.000. notice explicative. Col. Cartes \& Atlas. IFREMER, Plouzané (France), 48 pp.

Berné, S., B. Loubrieu and l'équipe Calmar embarquée. - 1999. Canyons et processus sédimentaires récents sur la marge occidentale du golfe du Lion. Premiers résultats de la campagne Calmar. C.R. Acad. Sci. Paris, Ser. IIA, 328: 471-477.

Bethoux, J.P., B. Gentili, P. Morin, E. Nicolas, C. Pierre and D. Ruiz-Pino. - 1999. The Mediterranean Sea: a miniature ocean for climatic and environmental studies and a key for the climate functioning of the North Atlantic. Progr. Oceanogr., 44: 131146.

Bianchini, M.L. and S. Ragonese (eds.). - 1994. Life cycles and fisheries of the deep-water red shrimps Aristaeomorpha foliacea and Aristeus antennatus. NTR-ITPP Spec. Publ. 3: 1-87.

Bianchini, M.L., L. Di Stefano and S. Ragonese. - 1998. Trawl mesh and selectivity and body engagement pattern in the red shrimp Aristaeomorpha foliacea (Risso, 1827) (Crustacea: Decapoda). J. Nat. Hist., 32: 1431-1437.

Boetius, A., S. Scheibe, A. Tselepides and H. Thiel. - 1996. Microbial biomass and activities in deep-sea sediments of the Eastern Mediterranean: trenches and benthic hotspots. Deep-Sea Res., 43: $1439-1460$.

Bombace, G. - 1975. Considerazioni sulla distribuzione delle popolazioni di livello batiale con particolare riferimento a quelle bentonectoniche. Pubbl. Staz. Zool. Napoli, 39(Supp. 1): 7-21.

Bouchet, P. and M. Taviani. - 1992. The Mediterranean deep-sea fauna: pseudopopulations of Atlantic species? Deep-Sea Res., 39: $169-184$

Bourcart, J. - 1960. Carte topographique du fond de la Méditerranée occidentale. Bull. Inst. Oceanogr., Monaco, 57: 20 pp.

Buscail, R., R. Pocklington, R. Daumas and L. Guidi. - 1990. Fluxes and budget of organic matter in the benthic boundary layer over the northwestern Mediterranean Margin. Cont. Shelf Res., 10(9-11): 1089-1122

Caddy, J.F. - 1993. Some future perspectives for assessment and management of Mediterranean fisheries. Sci. Mar., 57(2-3): 121-130.

Calafat, A. - 1993. Dynamique sédimentaire de la marge rhodanienne, Golfe du Lion. Ph.D. thesis. Université de Perpignan, 270 pp.

Canals, M. - 1999. Deep sea depositional systems. The building and destruction of a Mediterranean slope-apron. Contribution n ${ }^{\circ} 24$, MAST Advanced Study Course on the Mediterranean System. Barcelona, July 1999, 17 pp.

Canals, M., J. Serra and O. Riba. - 1982. Toponimia de la Mar Catalano-Balear. Boll. Soc. Hist. Nat. Balears, 26: 169-194.

Canals, M., J.L. Casamor, R. Urgeles, G. Lastras, A.M. Calafat, D. Masson, S. Berné, B. Alonso and M. De Batist. -2000 . The Ebro continental margin, western Mediterranean Sea: interplay between canyon-channel systems and mass wasting processes. In: H. Nelson and P. Weimer (eds.), Deep-water reservoirs of the world. GCS SEPM Foundation, 20th Annual Conference, Houston, TX, 152-174 (CD edition)

Carbonell, A., M. Carbonell, M. Demestre, A. Grau and S. Montserrat. - 1999. The red shrimp Aristeus antennatus (Risso, 1816), fishery and biology in the Balearic Islands, western Mediterranean. Fish. Res., 44: 1-13.

Carbonell, A. and M. Acevedo. - 2003. Application of non-equilibrium production models to the red shrimp (Aristeus antennatus Risso, 1816) fishery in the western Mediterranean. Fish. Res., 65: $323-334$.
Carlucci, R., M. Panza, G. Costantino and G. D’Onghia. - 2003. Osservazioni sullo sbarcato dei gamberi rossi (Aristeus antennatus e Aristaeomorpha foliacea) nella Marineria di Gallipoli (Mar Ionio). Biol. Mar. Medit., 10(2): 781-784.

Carpine, C. - 1970. Ecologie de l'étage bathyal dans la Méditerranée occidentale. Mem. Inst. Oceanogr. Monaco, 2: 1-146.

Carrassón, M., and J.E. Cartes. - 2002. Trophic relationships in a Mediterranean deep-sea fish community: partition of food resources, dietary overlap and connections with the Benthic Boundary Layer. Mar. Ecol. Prog. Ser., 241: 41-55.

Carter, T., J. Flanagan, C. Jones, F. Marchant, R. Murchison, J. Rebman, J. Sylvester and J. Whitney. - 1972. A new bathymetric chart and physiography of the Mediterranean Sea. In: A.D. Stanley and A.D. Dowden (eds.), The Mediterranean Sea: A Natural Sedimentation Laboratory, pp. 1-23. Hutchinson \& Ross, Stroudsbourg.

Cartes, J.E. - 1993. Deep-sea decapod fauna of the western Mediterranean: bathymetric distribution and biogeographic aspects. Crustaceana, 65(1): 29-40.

Cartes, J.E. - 1998. Feeding strategies and partitioning of food resources in deep-water decapod crustaceans (between 4002300 m). J. Mar. Biol. Ass. UK., 78(2): 509-524

Cartes, J.E. and M. Carrassón. - 2004. Influence of trophic variables on the depth-range distribution and zonation rates of deep-sea megafauna: the case of the Western Mediterranean assemblages. Deep-Sea Res., 51: 263-279.

Cartes, J.E. and F. Maynou. - 1998. Daily ration estimates and comparative study of food consumption in nine species of deepwater decapod crustaceans of the NW Mediterranean. Mar. Ecol. Prog. Ser., 171: 221-231.

Cartes, J.E. and F. Sardà. - 1989. Feeding ecology of the deepwater aristeid crustacean Aristeus antennatus. Mar. Ecol. Prog. Ser., 54: 229-238.

Cartes, J.E. and F. Sardà - 1992. Abundance and diversity of decapod crustaceans in the deep-Catalan Sea (Western Mediterranean). J. Nat. Hist., 26: 1305-1323.

Cartes, J.E. and F. Sardà. - 1993. Zonation of deep-sea decapod fauna in the Catalan Sea (Western Mediterranean). Mar. Ecol. Prog. Ser., 94: 27-34.

Cartes, J.E. J.B. Company and F. Maynou. - 1994. Deep-water decapod crustaceans communities in the northwestern Mediterranean: influence of submarine canyons and season. Mar. Biol. 120: 221-230.

Cartes, J., M. Elizalde and J. Sorbe. - 2001. Contrasting life-histories, secondary production, and trophic structure of Peracarid assemblages of the bathyal suprabenthos from the Bay of Biscay (NE Atlantic) and the Catalan Sea (NW Mediterranean). Deep-Sea Res., 48: 2209-2232.

Cartes, J.E., A. Grémare, F. Maynou, S. Villora-Moreno and A. Dinet. - 2002. Bathymetric changes in the distribution of particulate organic matter and associated fauna along a deep-sea transect down the Catalan sea slope (Northwestern Mediterranean). Progr. Oceanogr., 53: 29-56.

Cartes, J.E., F. Maynou, J. Moranta, E. Massutí, D. Lloris and B. Morales-Nin. - 2004. Patterns of bathymetric distribution among deep-sea fauna at local spatial scale: comparison of mainland vs. insular areas. Prog. Oceanogr., 60: 29-45.

Cau, A., A. Carbonell, M.C. Follesa, A. Mannini, G. Norrito, L. Orsi Relini, C.-Y. Politou, S. Ragonese and P. Rinelli. - 2002. MEDITS-based information on the deep-water red shrimps Aristaeomorpha foliacea and Aristeus antennatus (Crustacea: Decapoda: Aristeidae). Sci. Mar., 66(Suppl.2): 103-124.

CIESM. - 2003. Mare Incognitum? Exploring Mediterranean deepsea biology. CIESM Workshop Monographs, 23: 128 pp., Monaco.

Cita, M.B. - 1991. Development of a Scientific Controversy. In: D. W. Müller, J.A. McKenzie and H. Weissert (eds.), Controversies in Modern Geology, pp. 13-23. Academics Press, London.

Cita, M.B., C. Beghi, A. Camerlenghi, K.A. Kastens, F.W. McCoy, A. Nosetto, E. Parisi, F. Scolari and L. Tomadin. - 1984. Turbidites and megaturbidites from the Herodotus Abyssal Plain (Eastern Mediterranean) unrelated to seismic events. Mar. Geology, 55: 79-101

COM. - 2002. Communication from the Commission to the Council and the European Parliament. Laying down a Community Action Plan for the conservation and sustainable exploitation of fisheries resources in the Mediterranean Sea under the Common Fisheries Policy. 535: 1-37. 
Company, J.B. and F. Sardà. - 1998. Metabolic rates and energy content of deep-sea benthic decapod crustaceans in the Western Mediterranean Sea. Deep-Sea Res., 45(11): 1861-1881.

Company, J.B. and F. Sardà. - 2000. Growth parameters of deepwater decapod crustaceans in the Northwestern Mediterranean Sea: a comparative approach. Mar. Biol., 136(1): 79-90.

Company, J.B., J.E. Cartes and F. Sardà. - 2001. Biological patterns and near-bottom population characteristics of two pasiphaeid decapod crustacean species, Pasiphaea sivado (Risso, 1816) and Pasiphaea multidentata Esmark, 1866, in the Northwestern Mediterranean Sea. Mar. Biol., 139(1): 61-73.

Company, J.B., F. Sardà, P. Puig, J.E. Cartes and A. Palanques. 2003. Duration and timing of the reproductive periods of the decapod crustaceans dwelling across the continental margin of the NW Mediterranean Sea: is there a general pattern? Mar. Ecol. Prog. Ser., 261: 201-216.

Conan, P. and C. Millot. - 1995. Variability of the northern current off Marseilles, western Mediterranean Sea, from February to June 1992, Oceanol. Acta, 18( 2): 193-205.

Courp, T. and A. Monaco. - 1990. Sediment dispersal and accumulation on the continental margin of the Gulf of Lions: sedimentary budget. Cont. Shelf Res., 10: 1063-1087.

Danovaro, R., N. Della Croce, A. Eleftheriou, M. Fabiano, N. Papadopoulou, C. Smith and A. Tselepides. - 1995. Meiofauna of the deep Eastern Mediterranean Sea: distribution, and abundance in relation to bacterial biomass, organic matter composition and other environmental factors. Progr. Oceanogr., 36: 329-341.

Danovaro, R., A. Dinet, G. Duineveld and A. Tselepides. - 1999. Benthic response to particulate fluxes in different trophic environments: a comparison between the Gulf of Lions-Catalan Sea (western-Mediterranean) and the Cretan Sea (eastern Mediterranean). Prog. Oceanog., 44(1-3): 287-312.

Danovaro, R., A. Tselepides, A. Otegui and N. Della Croce. - 2000. Dynamics of meiofaunal assemblages on the continental shelf and deep-sea sediments of the south Aegean Sea (NE Mediterranean): relationships with seasonal changes in food supply. Prog. Oceanog., 46(2-4): 367-400.

Danovaro, R., A. Dell' Anno, M. Fabiano, A. Pusceddu and A. Tselepides. - 2001. Deep-sea ecosystem response to climate changes: the Eastern Mediterranean case study. Trends Ecol. Evol., 16(9): 505-510.

Danovaro, R., C. Gambi and N. Della Croce - 2002. Meiofauna hotspot in the Atacama Trench, eastern South Pacific Ocean. Deep-Sea Res., 49: 843-857.

Danovaro, R., A. Dell'Anno and A. Pusceddu. - 2004. Biodiversity response to climate change in a warm deep sea. Ecol. Letters, 7: 821-828.

De Bovée, F., L.D. Guidi and J. Soyer. - 1990. Quantitative distribution of deep-sea meiobenthos in the northwestern Mediterranean (Gulf of Lions). Cont. Shelf Res., 10: 1123-1145.

Demestre, M. - 1990. Biología pesquera de la gamba Aristeus antennatus (Risso, 1816) en el mar catalán. Ph.D. thesis, Universidad de Barcelona.

Demestre, M. and J. Lleonart. - 1993. Population dynamics of Aristeus antennatus (Decapoda: Dendrobranchiata) in the northwestern Mediterranean. Sci. Mar. 57(2-3): 183-189.

Demestre, M. and P. Martín. - 1993. Optimum exploitation of a demersal resource in the western Mediterranean: the fishery of the deep-water shrimp Aristeus antennatus (Risso, 1816). Sci. Mar., 57(2-3): 175-182

De Zio, V., N. Ungaro, A. Vlora and G. Strippoli. - 1998. Lo stock di nasello del basso Adriatico: struttura demografica e rendimenti di pesca della frazione catturata con palangaro di fondo. Biol. Mar. Medit., 5(2): 128-135.

Desbruyères, D., A. Guille and J. Ramos. - 1972. Bionomie benthique du plateau continental de la côte Catalane Espagnole. Vie Milieu, 23: 335-363.

Di Geronimo, I. - 1974. Molluschi bentonici in sedimenti recenti batiali e abissali dello Jonio. Conchiglie, 10: 133-172.

D’Onghia, G., P. Maiorano, A. Matarrese and A. Tursi. - 1998a. Distribution, biology and population dynamics of Aristaeomorpha foliacea (Risso, 1827) (Decapoda, Natantia, Aristeidae) in the north-western Ionian Sea (Mediterranean Sea). Crustaceana, 71(5): 518-544.

D’Onghia, G., R. Carlucci, P. Maiorano and M. Panza. - 2003a. Discards from deep-water bottom trawling in the Eastern-Central Mediterranean Sea and effects of mesh size changes. $J$.
Northw. Atl. Fish. Sci., 31: 245-261.

D’Onghia, G., F. Mastrototaro, P. Maiorano and M. Basanisi. 1998b. Selettività della rete a strascico utilizzata sui fondi di scarpata (250-750 m) dello Ionio (Mediterraneo Centrale). Biol. Mar. Medit., 5(2): 437-448.

D'Onghia, G., F. Mastrototaro, A. Matarrese, C.-Y. Politou and Ch. Mytilineou. $-2003 \mathrm{~b}$. Biodiversity of the upper slope demersal community in the eastern Mediterranean: preliminary comparison between two areas with and without trawl fishing. $J$. Northw. Atl. Fish. Sci., 31: 263-273.

D’Onghia, G., C.-Y. Politou, A. Bozzano, D. Lloris, G. Rotllant, L. Sion and A. Mastrototaro. - 2004. Deep-water fish assemblages in the Mediterranean Sea. Sci. Mar., 68(Suppl. 3): 87-99.

D'Onghia, G., D. Lloris, L. Sion, F. Capezzuto and M. Labropoulou. - 2004. Observations on the distribution, population structure and biology of Bathypterois mediterraneus Bauchot, 1962 in three areas of the Mediterranean Sea. Sci. Mar. 68(Suppl. 3): 163-170.

Dugdale, R.C. and F.R. Wilkerson. - 1988. Nutrient sources and primary production in the Eastern Mediterranean. Oceanol. Acta, 9: 178-184.

Duineveld, G., A. Tselepides, R. Witbaard, R.P.M. Bak, E.M. Berghuis, G. Nieuwland, J. van der Weele and A. Kok. -2000. Benthic-pelagic coupling in the oligotrophic Cretan Sea. Prog. Oceanogr., 46(2-4): 457-480.

Durrieu de Madron, X., E. García-Ladona, A. Palanques, M. Moll, P. Puig, A. Calafat, P. Rojo and J. Carbonne. - 1996. Topographic constraint of currents in the Northwestern Mediterranean. Ann. Geophys., 14C: 398

Eleftheriou, A., C.J. Smith and A. Tselepides. - 1996. Food Chains in the Aegean Sea. NATO SFS FISHECO Project, Final Report.

Fabres, J., A. Calafat, A. Sanchez-Vidal, M. Canals and S. Heussner. - 2002. Composition and spatio-temporal variability of particle fluxes in the Western Alboran Gyre, Mediterranean Sea. J. Mar. Syst., 33-34: 431-456.

Féral, J.P., J.G. Ferrand and A. Guille. - 1990. Macrobenthic physiological response to environmental fluctuations: The reproductive cycle and enzymatic polymorphism of a eurybathic seaurchin on the northwestern Mediterranean continental shelf and slope. Cont. Shelf Res. 10: 1147-1 155.

Fiege, D., M.N. Ben-Eliahu and K.-N. Papadopoulou. - 1994. Polychaeta of the Central and Eastern Mediterranean deep sea. 7th Deep Sea Biology Symposium, Hersonissos, Crete, 29 Sept-4 Oct 1994, abstr. p. 9

Fiege, D., I. Kroncke and R. Barnich. - 2000. High abundance of Myriochele fragilis Nilsen \& Holthe, 1985 (Polychaeta, Oweniidae) in the deep sea of the Eastern Mediterranean. Hydrobiologia, 426: 97-103.

Fiorentino, F., L. Orsi Relini, A. Zamboni and G. Relini. - 1998. Remarks about the optimal harvest strategy for red shrimps (Aristeus antennatus, Risso 1816) on the basis of the Ligurian experience. Cah. Opt. médit., 35: 323-333.

Finetti, I. - 1985. Structure and Evolution of the Central Mediterranean (Pelagian and Ionian Seas). In: D.J. Stanley and F-C. Wezel (eds.), Geological Evolution of the Mediterranean Basin, pp. 215-230. Spring-Verlag New York, Inc.

Fishelson, L. and B.S. Galil. - 2001. Gonad structure and reproductive cycle in the deep-sea hermaphrodite tripodfish, Bathypterois mediterraneus (Chlorophthalmidae, Teleostei). Copeia, 2: 556-560.

Flexas, M.M. - 2003. Mesoscale variability of the Northern Current and the role of bottom topography. Ph.D. thesis. Univ. Politècnica de Catalunya, Barcelona.

Font, J., C. Millot, J. Salas, A. Julià and O. Chic. - 1998. The drift of Modified Atlantic Water from the Alborán Sea to the eastern Mediterranean. Sci. Mar., 62(3): 211-216.

Forbes, E. - 1844. Report on the Mollusca and Radiata of the Aegean Sea, and on their distribution, considered as bearing on geology. Report of the 13th British Association for the Advancement of Science, London, 13: 130-193.

Fredj, G. and L. Laubier. - 1985. The deep Mediterranean benthos. In: M. Moraitou-Apostolopoulou and V. Kiortsis, (eds), Mediterranean Marine Ecosystems, NATO Conference Series, 8, pp. 109-145. Plenum Press, New York.

Fuda, J.L., G. Etiope, C. Millot, P. Favali, M. Calcara, G. Smriglio and E. Boschi. - 2002. Warming, salting and origin of the Tyrrhenian Deep Water. Geophys. Res. Lett., 29(19): 1898.

Gage, D.J., and P.A. Tyler. - 1990. Deep-sea biology: a natural his- 
tory of organisms at the deep-sea floor. Cambridge University Press, Cambridge, UK.

Gaillard, F., Y. Desaubies, U. Send and F. Schott. - 1997. A fourdimensional analysis of the thermal structure in the Gulf of Lion. J. Geophys. Res., 102(C6): 12515-12537.

Galil, B. S. and M. Goren. - 1994. The deep sea Levantine fauna, new records and rare occurrences. Sencken. Marit., 25(1/3): 41-52.

García-Rodríguez, M. - 2003. Characteristics and standardisation of a red shrimp, Aristeus antennatus (Risso, 1816), fishery off the Alicante gulf (SE Spain). Sci. Mar., 67(1): 63-74.

García-Rodríguez, M. and A. Esteban. - 1999. On the biology and fishery of Aristeus antennatus (Risso, 1816), (Decapoda, Dendrobranchiata) in the Ibiza Channel (Balearic Islands, Spain). Sci. Mar., 63(1): 27-37.

Gascard, J.C. - 1978. Mediterranean deep water formation baroclinic instability and oceanic eddies. Oceanol. Acta, 1(3): 315330 .

Gennesseaux, M. and J.R. Vanney. - 1979. Cartes bathymétriques du Basin algero-provençal. C. R. Somm. Soc. Geol. Fr., 4: 191198 (4 charts)

George, R.Y. and R.J. Menzies. - 1968. Further evidence for seasonal breeding cycles in the deep-sea. Nature, 220: 80-81.

George, C.L. and R.P. Higgins. - 1979. Eutrophic hadal benthic community in the Puerto Rico Trench. Ambio Special Reports, 6: 51-58.

Ghidalia, W. and F. Bourgois. - 1961. Influence de la témperature et de l'éclairement sur la distribution des crevettes des moyennes et grandes profondeurs. Stud. Rev. Gentile. Fish. Count. Medit., FAO, 16: 1-53.

Giordani, P., W.E. Helder, S. Miserochi, R. Danovaro and A. Malaguti. - 2002. Gradients of benthic-pelagic coupling and carbon budgets in the Adriatic and Northern Ionian Sea. J. Mar. Systems, 33-34: 365-387.

Goren, M. and B.S. Galil. - 1997. New records of deep-sea fishes from the Levant Basin and a note on the deep-sea fishes of the Mediterranean. Israel J. Zool., 43: 197-203.

Got, H., J-C. Aloïsi and A. Monaco. - 1985. Sedimentary Processes in Mediterranean Deltas and Shelves. In: D.J. Stanley and FC. Wezel (eds.), Geological Evolution of the Mediterranean Basin, pp. 355-376. Spring-Verlag New York, Inc.

Guidi-Guilvard, L. - 2002. DYFAMED-BENTHOS, a long timeseries benthic survey at 2347-m depth in the northwestern Mediterranean: general introduction. Deep-Sea Res., 49: 21832193.

Guille, A. - 1970. Bionomie benthique du plateau continental de la côte catalane française. II. Les communautés de la macrofaune. Vie Milieu, 21: 149-280.

Haedrich, R. and N. Merrett. - 1990. Little evidence for faunal zonation or communities in the deep demersal fish fauna. Progr. Oceanogr., 24: 239-250.

Hausmann, K., N. Hulsmann, I. Polianski, S. Schade and M. Weitere. - 2002. Composition of benthic protozoan communities along a depth transect in the eastern Mediterranean Sea. DeepSea Res., 49: 1959-1970.

Hieke, W. - 1984. A thick Holocene homogenite from the Ionian Abyssal Plain (Eastern Mediterranean). Mar. Geol., 55: 63-78.

Hopkins, T.S. - 1985. Physics of the sea. In: R. Margalef (ed.), Key Environments: Western Mediterranean, pp. 100-125. Pergamon Press, N.Y.

Hsü, K.J. - 1983. The Mediterranean was a Desert. Princeton Univ. Press.

Hsü, K.J., M.B. Cita and W.B.F. Ryan. - 1973. The origin of the Mediterranean evaporites. Init. Report. D. S. D. P., 13(2): 12031231.

Hsü, K.J., L. Montadert, D. Bernoulli, M.B. Cita, A. Eriksson, R.E. Garrison, R.B. Kidd, F. Melieres, C. Muller and R. Wright. 1977. History of the Mediterranean salinity crisis. Nature, 267: 399-403.

IBCM - 1981. International Bathymetric Chart of the Mediterranean 1/1.000.000 Intergovernmental Ocean. Comm., UNESCO. Edited by Head Depart. Navig. Oceanogr. Leningrad, USSR. 10 sheets.

Iudicone, D., B. Nardelli, R. Santoleri and S. Marullo. - 2003. Distribution and mixing of intermediate water masses in the Channel of Sicily (Mediterranean Sea). J. Geophys. Res., 108(C9): 8105-8111.

Janssen, R. - 1989. Benthic molluscs from the deepwater of the Eastern Mediterranean Sea, collected during "METEOR" - cruise 5 (1987). Sencken. Marit., 20: 265-276.

Jeffreys, J.G. - 1881. On the mollusca procured during the "Lightning" and "Porcupine" expeditions, 1868-70. Part III. Proc Zool. Soc. London, 25: 693-724.

Jeffreys, J.G. - 1883. Mediterranean Mollusca, No 3, and other Invertebrata. Ann. Mag. Nat. Hist., 5: 393-401.

Jordi, A., A. Orfila, G. Basterretxea and J. Tintoré. (in press). Shelfslope exchanges by frontal variability in a steep submarine canyon. Prog. Oceanogr.

Karakassis, J. and A. Eleftheriou. - 1997. The continental shelf of Crete: structure of macrobenthic communities. Mar. Ecol. Prog. Ser., 160: 185-196.

Kastens, K.A. and M.B. Cita. - 1981. Tsunami-induced sediment transport in the abyssal Mediterranean Sea. Geol. Soc. Am. Bull., 92: 845-857.

Koslow, J.A. - 1993. Community structure in North Atlantic deepsea fishes. Prog. Oceanogr., 31:.321-338.

Koslow, J.A., G.W. Boehlert, J.D.M. Gordon, R.L. Haedrich, P. Lorance and N. Parin. - 2000. Continental slope and deep-sea fisheries: implications for a fragile ecosystem. ICES J. Mar. Sci., 57: 548-557.

Koutsoubas, D., A. Koukouras, I. Karakassis and C. Dounas. 1992. Contribution to the knowledge of Gastropoda and Bivalvia (Mollusca) of Crete island (S. Aegean Sea). Boll. Malacol., 28: 69-82.

Koutsoubas, D., A. Tselepides and A. Eleftheriou. - 2000. Deep sea molluscan fauna of the Cretan Sea (Eastern Mediterranean): faunal, ecological and zoogeographical remarks. Sencken. Marit., 30(3/6): 85-98.

Krijgsman, W., F.J. Hilgen, I. Raffi, F.J. Sierro and D.S. Wilson. 1999. Chronology, causes and progression of the Messinian salinity crisis. Nature, 400: 652-655.

Kröncke I., M. Turkay and D. Fiege. - 2003. Macrofauna communities in the Eastern Mediterranean Sea. P.S.Z.N. Mar. Ecol., 24(3): 193-216.

Lascaratos, A., W. Roether, K. Nittis and B. Klein. - 1999. Recent changes in deep water formation and spreading in the eastern Mediterranean Sea: a review. Progr. Oceanogr., 44: 5-36.

Ledoyer, M. - 1969. Aperçu sur la faune vagile de quelques biotopes de substrat dur de Méditerranée orientale comparaison avec les mêmes biotopes en Méditerranée occidentale. Tethys, 1: 281-290.

Lastras, G., M. Canals, J.E. Hughes-Clarke, A. Moreno, M. de Batist, D.G. Masson and P. Cochonat. - 2002. Sea-floor imagery of the BIG'95 debris flow, Western Mediterranean. Geology, 30: 871-874.

Lipiatou, E. (ed.). - 1997. Interdisciplinary research in the Mediterranean Sea: A synthesis of scientific results from the Mediterranean Targeted project (MTP) phase I, 1993-1996. Research in Enclosed Sea Series, 1: 1-344. European Communities, Luxembourg.

Lipiatou, E., S. Heussner, R. Mossetti, J.Tintoré and A. Tselepides. (eds.) - 1999. Progress in oceanography of the Mediterranean Sea. Progr. Oceanogr., 44(1-3): 3-468

Lykousis, V., G. Chronis, A. Tselepides, A.. Theocharis, B. Price, L. Ignatiades, I. Siokou-Frangou, S. Stavrakakis, F.V. Wambeke, G. Danovaro, D. Georgopoulos and A. Souvermezoglou. - 2002. Major outputs of the recent multidisciplinary biogeochemical reseach in the Aegean Sea. J. Mar. Syst., 3334: 313-334

Machias, A., P. Maiorano, V. Vassilopoulou, C. Papaconstantinou, A. Tursi and N. Tsimenides. - 2004. Sizes of discarded commercial species in the eastern-central Mediterranean Sea. Fish. Res., 66(2-3): 213-222.

MacKenzie, J.A. - 1999. From desert to deluge in the Mediterranean. Nature, 400: 613-614.

Maldonado, A. - 1985. Evolution of the Mediterranean Basins and a Detailed Reconstruction of the Cenozoic Palaeoceanography. In: R. Margalef (ed.), Western Mediterranean, 17-59. Pergamon Press, Oxford.

Martínez-Baños, P. - 1997. Dinámica de poblaciones de la gamba Aristeus antennatus (Crustacea Decapoda) en las zonas de Múrcia, Almería e Ibiza. Análisis global en el Mediterráneo Español. Ph.D. thesis. University of Murcia.

Martínez-Ruíz, F., A. Paytan, M. Kastner, J.M. González-Donoso, D. Linares, M. Berbasconi and F.J. Jiménez-Espejo. - 2003. A comparative study of the geochemical and mineralogical characteristics of the S1 sapropel in the western and eastern 
Mediterranean. Palaeogeogr., Palaeoclimat., Palaeoecol., 190: 23-37.

Marenzeller, E. - 1893. Berichte der Commission fur Erforschung des ostlichen Mittelmeeres, V. Zoologische Ergebnisse. I. Echinodermen, gesammelt 1890, 1891, und 1892. Denkschriften der Akademie der Wissenschaften, Wien, 60: 1-24.

Massutí, E., J.D.M. Gordon, J. Moranta, S.C. Swan, C. Stefanescu and N.R. Merrett. - 2004. Mediterranean and Atlantic deep-sea fish assemblages: differences in biomass composition and sizerelated structure. Sci. Mar., 68(Suppl. 3): 101-115.

Massutí, M., and E. Daroca. - 1978. Introducción al studio de la biología de Aristeus antennatus de las pesquerías del sur de Mallorca. Trab. Comp. Dept. de Pesca (IEO): 264-277.

Mastrototaro, F., A. Matarrese and A. Tursi. - 2002. Un mare di coralli in Mar Ionio. Biol. Mar. Medit., 9(1): 616-619.

Matarrese, A., G. D’Onghia, A. Tursi and P. Maiorano. - 1997. Vulnerabilità e resilienza di Aristaeomorpha foliacea (Risso, 1827) e Aristeus antennatus (Risso, 1816) (Crostacei, Decapodi) nel Mar Ionio. S. It. E. Atti, 18: 535-538.

Maurin, C. - 1965a. Les crevettes profondes de la region Atlantique Ibéro-Marocaine: répartition bathymètrique et géographique, importance économique. Rapp. Proc. Verb., CIESM, 156(20): 116-119.

Maurin, C. - 1965b. Répartition des crevettes profondes au large des côtes de Sardagne et Corse. Rapp. P. - V. Réun., 18(2): 175178.

Maynou, F. and J.E. Cartes. - 1998. Food consumption by bathyal decapod crustacean assemblages in the western Mediterranean predatory impact of megafauna and the food consumption-food supply balance in a deep-water food web. Mar. Ecol. Prog. Ser., 171: 233-246.

Maynou, F., M. Demestre and P. Sánchez. - 2003. Analysis of catch per unit effort by multivariate analysis and generalised linear models for deep-water crustacean fisheries off Barcelona (NW Mediterranean). Fish. Res., 65: 257-269.

MEDOC Méditerranée Occidentale Group. - 1970. Observation of formation of deep water in the Mediterranean. Nature, 227 : 1037-1040.

Menzies, R.J. - 1962. On the food and feeding habits of abyssal organisms as exemplified by the Isopoda. Inter. Rev. ges Hydrobiology, 47: 339-358.

Menzies, R.J., R.Y. George and G. T. Rowe. - 1973. Abyssal Environment and Ecology of the World Oceans. Wiley-Interscience, New York.

Merrett, R., and R. Haedrich. - 1997. Deep-sea demersal fish and fisheries. Chapman \& Hall, London.

Millot, C. - 1994. Models and data: a synergetic approach in the western Mediterranean Sea. In: P. Malanotte-Rizzoli and A.R. Robinson (eds.), Ocean Processes in Climate Dynamics: Global and Mediterranean Examples, Kluwer.

Millot, C. - 1999. Circulation in the western Mediterranean Sea (Review paper). J. Mar. Syst., 20: 423-442.

Millot, C., M. Benzhora and I. Taupier-Letage. - 1997. Circulation off Algeria inferred from the MEDIPROD-5 current meters. Deep-Sea Res., 44(9-10): 1467-1495.

Monaco, A., J. M. Beckers, M. Canals, V. Lykousis, R. Mosetti, N.B. Price, E. Lipiatou and B. Charriere. - 2002. MATER Mass Transfer and Ecosystem Response. An integrated and multiscale approach of the Mediterranean system. J. Mar. Syst., 33-34 Sp. Iss.

Monaco, A., P.E. Biscaye, J. Soyer, R. Pocklington and S. Heussner. - 1990. Particle fluxes and ecosystem response on a continental margin: the 1985-1988 Mediterranean ECOMARGE experiment. Cont. Shelf Res., 10: 809-839.

Monti, S., J.M. Auzende, J.L. Olivet, A. Mauffret and J.P. Rehault. - 1978. Carte Bathymétrique de la Méditerranée Occidentale au 1/500000. B.R.G. M. (ed.), Paris.

Morales-Nin, B., F. Maynou, F. Sardà, J.E. Cartes, J. Moranta, E. Massutí, J.B. Company, G. Rotllant, A. Bozzano and C. Stefanescu. - 2004. Size influence in zonation patterns in fishes and crustaceans from deep-water communities of the western Mediterranean. NAFO J. Northwest Atl. Fish. Sci., 31: 413430.

Moranta, J., C. Stefanescu, E. Massutí, B. Morales-Nin and D. Lloris. - 1998. Fish community structure and depth-related trends on the continental slope of the Balearic Islands (Algerian basin, western Mediterranean). Mar. Ecol. Prog. Ser., 171: 247-259.

Moranta, J., M. Palmer, E. Massutí, C. Stefanescu and B. Morales-
Nin. - 2004. Body fish size tendencies within and among species in the deep-sea of the western Mediterranean. Sci. Mar., 68(Suppl. 3): 141-152.

Mura, M., S. Saba and A. Cau. - 1998. Feeding habits of demersal aristeid crustaceans in the Central-western Mediterranean Sea. Anim. Biol., 7:3-10.

Murenu, M., D. Cuccu, C. Follesa, A. Sabatini and A. Cau. - 1994. The occurrence of Aristaeomorpha foliacea in Sardinian waters. In: M. Bianchini and S. Ragonese (eds.), Life cycles and fisheries of the deep-water red shrimps Aristaeomorpha foliacea and Aristeus antennatus. N.T.R. - I.T.P.P. Special Publ., 3: 49 .

Mytilineou, Ch. and C.-Y. Politou. - 1997. New records for the presence of the red shrimp, Aristaeomorpha foliacea (Risso, 1827) in the Greek waters. Proc. 5th Panhel. Symp. Ocean. Fish., Kavala, April 1997, Vol. II: 87-89.

Naudin, J.J. and G. Cauwet. - 1997. Transfer mechanisms and biogeochemical implications in the bottom nepheloid layer. A case study of the coastal zone off the Rhone River (France). DeepSea Res., 44(34): 551-575.

Obaton, D., C. Millot, G. Chabert d'Hières and I. Taupier-Letage. 2000. The Algerian current: comparisons between in situ and laboratory measurements. Deep-Sea Res., 47: 2159-2190.

Onken, R., A.R. Robinson, P.F.J. Lermusiaux, P.J. Haley Jr. and L.A. Anderson. - 2003. Data-driven simulations of synoptic circulation and transports in the Tunisia-Sardinia-Sicily region. J. Geophys. Res., 108(C9): 8123.

Orsi Relini, L. and G. Relini. -1985 . The red shrimps fishery in the Ligurian Sea: Mismanagement or not?. FAO, Fish. Rep., 336: 99-106.

Orsi Relini, L. and G. Relini. - 1988. An uncommon recruitment of Aristeus antennatus (Risso) (Crustacea Decapoda Aristeidae) in the Gulf of Genova. Rapp. Comm. int. Mer Médit., 31(2): 10.

Papaconstantinou, C. and K. Kapiris. - 2001. Distribution and population structure of the red shrimp (Aristeus antennatus) on an unexploited fishing ground in the Greek Ionian Sea. Aquat. Liv. Res., 14: 303-312.

Papaconstantinou, C. and K. Kapiris. - 2003. The biology of the giant red shrimp (Aristaeomorpha foliacea) at an unexploited fishing ground in the Greek Ionian Sea. Fish. Res., 62: 37-51.

Papaconstantinou, C. and K.I. Stergiou. - 1995. Biology and fisheries of eastern Mediterranean hake (M. merluccius). In: J. Alheit and T. Pitcher (eds.), Hake: Biology, fisheries and markets, pp. 149-180. Chapman and Hall, London.

Pérès, J.M. - 1982. Zonations: General features of organismic assemblages in pelagial and benthal. In: O. Kinne, (ed.), Marine Ecology Vol. 1, John Wiley, Chichester.

Pérès, J. M. - 1985. History of the Mediterranean biota and the colonization of the depths. In: R. Margalef (ed.), Western Mediterranean, pp. 198-232. Pergamon Press.

Pérès, J.M. and J. Picard. - 1958. Recherches sur les peuplements benthiques de la Méditerranée Nord - Orientale. Ann. Inst. Océanogr., Paris, 34: 213-281.

Pfannkuche, O., R. Theeg and H. Thiel. - 1983. Benthos activity, abundance and biomass under an area of low upwelling of Morocco, Northwest Africa. Meteor Forschungs Ergebnisse, 36: $85-96$.

Pfannkuche, O. - 1985. The deep-sea meiofauna of the Porcupine Seabight and abyssal plain (NE Atlantic): population structure, distribution, standing stocks. Oceanol. Acta, 8: 343-353.

Pierrot, S. - 1972. Carte Bathymétrique de la Mer Ligure. Musée d'Océanographie, Monaco, scale 1:50.000.

Politou, C. - Y., S. Kavadas, Ch. Mytilineou, A. Tursi, R. Carlucci and G. Lembo. - 2003. Fisheries Resources in the Deep Waters of the Eastern Mediterranean (Greek Ionian Sea). J. Northw. Atl. Fish. Sci., 31: 35-46.

Politou, C.Y., K. Kapiris, P. Maiorano, F. Capezzuto and J. Dokos. - 2004. Deep-sea Mediterranean biology: the case of Aristaeomorpha foliacea (Risso, 1827) (Crustacea: Decapoda: Aristeidae). Sci. Mar., 68(Suppl. 3): 129-139.

Psarra, S., A. Tselepides and L. Ignatiades. - 2000. Primary productivity in the oligotrophic Cretan Sea (NE Mediterranean): seasonal and interannual variability. Prog. Oceanogr., 46: 187204.

Puig, P. and A. Palanques. - 1998a. Nepheloid structure and hydrographic control on the Barcelona continental margin, northwestern Mediterranean. Mar. Geol., 149: 39-54

Puig, P. and A. Palanques. - 1998b. Temporal variability and compo- 
sition of settling particle fluxes on the Barcelona continental margin (Northwestern Mediterranean). J. Mar. Res., 56: 639-654.

Puig, P., A. Palanques, J. Guillen and E. García-Ladona. - 2000. Deep slope currents and suspended particle fluxes in and around the Foix submarine canyon (NW Mediterranean). DeepSea Res., 47: 343-366

Puig, P., J.B. Company, F. Sardà and A. Palanques. - 2001. Responses of deep-water shrimp populations to the presence of intermediate nepheloid layers on continental margins. DeepSea Res., 48: 2195-2207.

Rabitti, S., F. Bianchi, A. Bolfrin, L. Da Ros, G. Socal and C. Totti. - 1994. Particulate matter and phytoplankton in Ionian Sea. Oceanol. Acta, 17(3): 297-307.

Ragonese, S. - 1995. Geographical distribution of Aristaeomorpha foliacea (Crustacea, Aristeidae) in the Sicilian Channel (Mediterranean Sea). ICES Mar. Sci. Symp., 199: 183-188.

Ragonese, S. and M.L. Bianchini. - 1995. Size at sexual maturity in red shrimp females, Aristaeomorpha foliacea, from the Sicilian Channel (Mediterranean Sea). Crustaceana, 68(1): 73-82.

Ragonese, S. and M.L. Bianchini. - 1996. Growth, mortality and yield-perrecruit of the deep-water shrimp Aristeus antennatus (Crustacea: Aristeidae) of the Strait of Sicily (Mediterranean Sea). Fish. Res., 26: 125-137.

Ragonese, S., M. Zagra, L. Di Stefano and M.L. Bianchini. - 2001. Effect of codend mesh size on the performance of the deepwater bottom trawl used in the red shrimp fishery in the Strait of Sicily (Mediterranean Sea). Hydrobiologia, 449: 279-291.

Raulin, V. - 1870. Description physique de l'île de Crete. Actes Soc. Linn. Bordeaux, 24: 353-770.

Relini, G. - 1998. Valutazione delle risorse demersali. Biol. Mar. Medit., 5: 3-19.

Relini, G., J. Bertrand and A. Zamboni (eds.). - 1999. Synthesis of the knowledge on bottom fishery resources in Central Mediterranean, Italy and Corsica. Biol. Mar. Medit., 6(Suppl. 1): 868 pp..

Relini, G., F. Biagi, F. Serena, A. Belluscio, M.T. Spedicato, P. Rinelli, M.C. Follesa, C. Piccinetti, N. Ungaro, L. Sion and D. Levi. - 2000. I Selaci pescati con lo strascico nei mari italiani. Biol. Mar. Medit., 7(1): 347-384.

Relini, G. and L. Relini Orsi. - 1987 -The decline of red shrimps stocks in the Gulf of Genova. Inv. Pesq., 51(1): 254-260.

Rehault, J.P., G. Boillot and A. Mauffret. - 1985. The Western Mediterranean Basin. In: D.J. Stanley and F-C. Wezel (eds.), Geological Evolution of the Mediterranean Basin, pp. 101-129. Spring-Verlag New York, Inc.

Robinson A.R. and M. Golnaraghi. - 1992. Progress in the understanding of the eastern Mediterranean Sea. Bull. Inst. Océanogr., Monaco, 11: 65-73.

Roca, E., M. Sans, L. Cabrera and M. Marzo. - 1999. Oligocene to middle Miocene evolution of the central Catalan margin northwestern Mediterranean). Tectonophysics, 315: 209- 233.

Roether, W., B.B. Manc, B. Klein, D. Bregant, D. Georgopoulos, V. Beitzel, V. Kocacevic and A. Luchetta. - 1996. Recent changes in eastern Mediterranean deep waters. Science, 271: 333-335.

Rothwell, R.G., J. Thomson and G. Kähler. - 1998. Low sea-level emplacement of a very large Late Pleistocene "megaturbidite" in the western Mediterranean Sea. Nature, 392: 377-380.

Rothwell, R.G., M.S. Reeder, G. Anastasakis, D.A.V. Stow, J. Thomson and G. Kähler. - 2000. Low-stand emplacement of megaturbidites in the Western and Eastern Mediterranean Sea. Sediment. Geol., 135: 75-88.

Rotllant, G., J. Moranta, E. Massuti, F. Sardà and B. Morales-Nin. - 2002. Reproductive biology of three gadiform species through the Mediterranean deep-sea range (147-1850 m). Sci. Mar., 66(2): 157-166.

Rucabado, J., D. Lloris and C. Stefanescu. - 1991. OTSB14: un arte de arrastre bentónico para la pesca profunda (por debajo de los mil metros). Inf. Tec. Sci. Mar., 165: 1- 27.

Ryan, W.B.F., K.J. Hsü. - 1973. Initials Reports of the Deep Sea Drilling Project, vol. 13. Nat. Sci. Found. Washington, D.C., pp. 1047.

Salas, C. - 1996. Marine bivalves from off the southern Iberian peninsula collected by the BALGIM and Fauna 1 Expeditions. Haliotis, 25: 33-100.

Salihiglu, I., C. Saydam, O. Basturk, K. Yilmaz, D. Go, E. Hatipoglu and A. Yilmaz. - 1990. Transport of nutrients and chlorophyll-a by mesoscale eddies in the northeastern Mediterranean. Mar. Chem., 29: 375-390.

Sarà, M. - 1985. Ecological factors and their biogeographic conse- quences in the Mediterranean Ecosystems. In: M. MoraitouApostolopoulou and V. Kiortsis, (eds.), Mediterranean Marine Ecosystems, pp. 1-17. NATO Conference Series, Vol. 8, Plenum Press, New York

Sardà, F. - 1993. Bio-ecological aspects of the decapod crustacean fisheries in the Western Mediterranean. Aquat. Liv. Resour., 6: 299-305.

Sardà, F. - 2001. Exploratory survey to collect data of the exploited and virgin stocks of deep-sea shrimp A. antennatus, of interest to the CFP. Final Report, E.C. D.G. VIX, Study Contract 2000/39.

Sardà, F. and J.E. Cartes. - 1993. Relationship between size and depth in decapod crustacean populations on the deep slope in the Western Mediterranean. Deep-Sea Res., 40 (11/12): 23892400 .

Sardà, F. and J.E. Cartes. - 1997. Morphological features and ecological aspects of early juvenile specimens of the aristeid shrimp Aristeus antennatus (Risso, 1816). Mar. Freshw. Res., 48: 73-77.

Sardà, F, and M. Demestre. - 1987. Estudio biológico de la gamba Aristeus antennatus (Risso, 1816) en el Mar Catalán (NE de España). Inv. Pesq., 51(Suppl. 1): 213-232.

Sardà, F. and P. Martín. - 1986. Las pesquerías a Catalunya (evolució en els ultims decennis) In: l'Oceanografia, Recursos Pesquers de la Mar Catalana. Quaderns d'Ecología Aplicada, Diputació de Barcelona, Servei Medi Ambient, 9: 91-112.

Sardà, F., J.E. Cartes and W. Norbis. - 1994. Spatio-temporal structure of the deep-water shrimp Aristeus antennatus Risso, 1816 (Decapoda: Aristeidae) population in the Western Mediterranean. Fish. Bull. NOAA, 92(3): 599-607.

Sardà, F., F. Maynou and Ll. Talló. - 1998. Seasonal and spatial mobility patterns of rose shrimp (Aristeus antennatus Risso, 1816) in the western Mediterranean: results of a long-term study. Mar. Ecol. Prog. Ser., 159: 133-141.

Sardà, F., J.B. Company and F. Maynou. - 2003a. Deep-sea shrimp Aristeus antennatus Risso 1816 in the Catalan sea, a review and perspectives. NAFO J. Northw. Atl. Fish. Sci., 31: 127-136.

Sardà, F., J.B. Company and A. Castellón. - 2003b. Intraspecific aggregation structure of a shoal of a western Mediterranean (Catalan coast) deep-sea shrimp, Aristeus antennatus (Risso, 1816), during the reproductive period. J. Shellfish Res., 22(2): 569-579.

Sardà, F., G. D’Onghia, C.Y., Politou, J.B. Company, P. Maiorano and K. Kapiris. - 2004. Deep-sea distribution, biological and ecological aspects of Aristeus antennatus (Risso, 1816) in the western and central Mediterranean sea. Sci. Mar., 68(Suppl. 3): $117-127$.

Selli, R. - 1985. Tectonic evolution of the Tyrrhenian sea. In: D.J. Stanley and F-C. Wezel (eds.), Geological Evolution of the Mediterranean Basin, pp. 131-152. Spring-Verlag New York, Inc.

Séranne, M. - 1999. The Gulf of Lion continental margin (NW Mediterranean) revisited by IBS: an overview. In: B. Durand, L. Jolivet, F. Horváth and M. Séranne (eds.), The Mediterranean Basins: Tertiary extension within the Alpine Orogen, pp. 15-36. The Geological Society, Special Publication 156.

Shirayama, Y. - 1984. The abundance of deep sea meiobenthos in the western Pacific in relation to environmental factors. Oceanol. Acta, 7: 113-121.

Shirayama, Y. and S. Kojima. - 1994. Abundance of deep-sea meiobenthos off Sanriku, Northeastern Japan. J. Oceanogr., 50: 109-117.

Sibuet, M., C.E. Lamberti, R. Chesselet and L. Laubfer. - 1989. Density of the major size groups of benthic fauna and trophic input in deep basins of the Atlantic Ocean. J. Mar. Res., 47: 851-867.

Soetaert, K., C. Heip and M. Vincx. - 1991a. Diversity of nematode assemblages along a Mediterranean deep-sea transect. Mar. Ecol. Progr. Ser., 75: 275-282.

Sparnocchia, S., G.P. Gasparini, M. Borghini, and P. Pistek. - 1999. Dynamics and mixing of the eastern Mediterranean outflow in the Tyrrhenian Sea. In: M. Gacic, M. Astraldi and P.E. La Violette (eds.), The Mediterranean Sea, Circulation, Strait Exchange and Dense Water Formation. J. Mar. Sys., 20: 301-332.

Bertrand, J.A., L. Gil de Sola, C. Papaconstantinou, G. Relini and A. Souplet. - 2002. The general specifications of the MEDITS surveys. Sci. Mar., 66(Suppl. 2): 9-17.

Soyer, M. - 1985. Mediterranean Sea meiobenthos. In: M. Moraitou-Apostolopoulou and V. Kiortsis (eds.). Mediter- 
ranean marine ecosystems, pp. 85-108. NATO Conference Series, Vol. 8, Plenum Press, New York.

Stanley, D.J. - 1972. The Mediterranean Sea: a natural sedimentation laboratory. Dowden, Hutchinson \& Ross, Stroudsbourg, PA, pp. 765

Stanley, D.J. - 1977. Post-Miocene depositional patterns and structural displacement in the Mediterranean. In: A.E.M. Nairn, W.H. Kanes and F.G. Stheli (eds.), The oceans basins and margins: the Eastern Mediterranean, pp. 77-128. Plenum Press, New York.

Stanley, D.J. - 1985. Mud depositional processes as a major influence on Mediterranean margin-basin sedimentation. In: D.J. Stanley and F-C. Wezel (eds.), Geological evolution of the Mediterranean Basin, pp. 377-410. Spring-Verlag New York, Inc.

Stanley, D.J., F.W. McCoy and L. Diester-Haass. - 1974. Balearic abyssal plain: an example of modern basin plain deformation by salt tectonism. Mar. Geol., 17: 183-200

Stanley, D.J. and A. Maldonado. - 1981. Depositional models for fine-grained sediment in the western Hellenic Trench. Eastern Mediterranean. Sedimentology, 28: 273-290.

Stanley, D.J. and F.-C. Wezel (eds.). - 1985. Geological Evolution of the Mediterranean Basin. Spring-Verlag, New York, Inc.

Stavrakakis, S., G. Chronis, T. Tselepides, S. Heussner, A. Monaco and A. Abassi. - 2000. Downward fluxes of settling particles in the deep Cretan Sea (NE Mediterranean). Prog. Oceanogr., 46: 217-240.

Stefanescu, C., D. Lloris and J. Rucabado. - 1992. Deep-living demersal fishes in the Catalan Sea (western Mediterranean) below a depth of $1000 \mathrm{~m}$. J. Nat. Hist., 26: 197-213.

Stefanescu, C., D. Lloris and J. Rucabado. - 1993. Deep-living fish assemblages in the Catalan Sea (western Mediterranean) below a depth of 1000 m. Deep-Sea Res., 40: 695-707.

Stefanescu, C., B. Morales-Nin and E. Massutí. - 1994. Fish assemblages on the slope in the Catalan sea (western Mediterranean): Influence of a submarine canyon. J. Mar. Biol. Ass. UK, 74: 499-512.

Stergiou, K.I., G. Petrakis and C.-Y. Politou. - 1996. Small-scale fisheries in the south Euboikos Gulf (Greece): species composition and gear competition. Fish. Res., 26: 325-336.

Stergiou, K.I., C. Christou, D. Georgopoulos, A. Zenetos and C. Souvermezoglou. - 1997. Hellenic waters: physics, chemistry, biology and fisheries. Oceanogr. Mar. Biol., 35: 415-538.

Stergiou, K.I., C. Papaconstantinou and G. Petrakis. - 1989. Fisheries production in the Patraikos and Korinthiakos Gulfs and the Ionian Sea. 1980-1985. In: Proceedings of the Second Hellenic Symposium on Oceanography and Fisheries, 2: 571-576 (in Greek with English abstract).

Stora, G., M. Bourcier, A. Arnoux, M. Gerino, J. Campion, F. Gilbert and J.P. Durbec. - 1999. The deep-sea macrobenthos on the continental slope of the northwestern Mediterranean Sea: a quantitative approach. Deep-Sea Res., 46: 1339-1368.

Sturany, R. - 1896. Zoologische Ergebnisse. VII. Mollusken I (Prosobranchier und Opisthobranchier, Scaphopoden. Lamellibranchier) gesammelt von S.M. Schiff "Pola" 1890-1894 Denkschre K.K. Akademie Wiss Mathematich Naturw Wien, 63: 1-36.

Sverdrup, H.U., M.W. Johnson and R.H. Fleming. - 1942. The oceans, their physics, chemistry and general biology. PrenticeHall, Inc. New York.

Tahey, T., G. Duineveld, E. Berghuis and W. Helder. - 1994. Relation between sediment-water fluxes of oxygen and silicate and faunal abundance at continental shelf, slope and deep-water stations in the northwest Mediterranean. Mar. Ecol. Prog. Ser., 104: 119-130.

Taupier-Letage, I. and C. Millot. - 1988. Surface circulation in the Algerian Basin during 1984. Oceanol. Acta, 9: 119-131.

Tchukhtchin, V. D. - 1964. Quantitative data on benthos of the Tyrrhenean Sea. Trudy Sevastopol Biological Station, 17: 48-50.

Testor, P. and J.-C. Gascard.- 2003. Large-scale spreading of deepsea waters in the western Mediterranean sea by submesoscale coherent eddies. J. Phys. Oceanogr., 33: 75-87.

Theocharis, A., D. Georgopoulos, A. Lacsaratos and K. Nittis. 1993. Water masses and circulation in the central region of the Eastern Mediterranean: Eastern Ionian, South Aegean and Northwest Levantine, 1986-1987. Deep-Sea Res. II, 40(6): 1121-1142.

Thiel, H. - 1979a. Structural aspects of deep-sea benthos. Ambio, 6: $25-31$.
Thiel, H. - 1983. Meiobenthos and Nanobenthos of the deep sea. In: G. Rowe (ed.), Deep-sea Biology, pp. 167-230. Wiley Interscience, New York.

Tietjen, J.H., J.W. Deming, G.T. Rowe, S. Macko and R.J. Wilke. - 1989. Meiobenthos of the Hatteras Abyssal Plain and Puerto Rico Trench: abundance, biomass and associations with bacteria and particulate fluxes. Deep-Sea Res., 36: 1567-1577.

Tietjen, J.H. - 1992. Abundance and biomass of metazoan meiobenthos in the deep sea. In: G.T. Rowe and V. Pariente (eds.), Deep-sea food chains and the global carbon cycle, pp. 45-62. Kluwer Acad. Publishers.

Tobar, R. and F. Sardà. - 1987. Análisis de las capturas de gamba en los últimos decenios en Cataluña. Inf. Téc. Inst. Inv. Pesq., 142: 1-20.

Tselepides, A. - 1992. Ecological study of the bathyal ecosystem of the Aegean Sea. Ph.D. thesis, University of Crete (in Greek).

Tselepides, A. - 1994. Macrobenthic communities of the continental slope of the Aegean Sea. 7th Deep Sea Biology Symposium, Hersonissos, Crete, 29 Sept-4 Oct 1994, abstr. p.30.

Tselepides, A. and A. Eleftheriou. - 1992. South Aegean (Eastern Mediterranean) continental slope benthos: macroinfaunal environmental relationships. In: G.T. Rowe and V. Pariente (eds.), Deep-sea food chains and the global carbon cycle, pp. 139-156. Kluwer Acad. Publications, Dordecht.

Tselepides, A. and N. Lampadariou. - 2004. Deep-sea meiofaunal community structure in the Eastern Mediterranean: are trenches benthic hot-spots? Deep-Sea Res., 51: 833-874.

Tselepides, A. and T. Polychronaki. - 2000. The CINCS project: introduction. Prog. Oceanogr., 46(2-4): 85-88.

Tselepides, A., N. Papadopoulou, D. Podaras, W. Plaiti and D. Koutsoubas. - 2000. Macrobenthic community structure over the continental margin of Crete (South Aegean Sea, NE Mediterranean). Prog. Oceanogr., 46(2-4): 401-428.

Tselepides, A., T. Polychronaki, D. Marrale, I. Akoumianaki, A. Dell' Anno, A. Pusceddu and R. Danovaro. - 2000a. Organic matter composition of the continental shelf and bathyal sediments of the Cretan Sea. Prog. Oceanogr., 46: 311-344.

Tudela, S., F. Sardà, F. Maynou and M. Demestre. - 2003. Influence of submarine canyons on the distribution of the deepwater shrimp (Aristeus antennatus, Risso 1816) in the northwestern Mediterranean. Crustaceana, 76(2): 217-225.

Tursi, A., G. D’Onghia, A. Matarrese and C. Caroppo. - 1993. L'importanza dei Crostacei Decapodi (Natanti e Reptanti Macruri) nel contesto delle campagne di pesca condotte nel Mar Ionio (1985-1986). Quad. Lab. Tecnol. Pesca., 5(2): 145-158.

Tursi, A., A. Matarrese, G. D'Onghia, P. Maiorano and M. Panza. - 1998. Sintesi delle ricerche sulle risorse demersali del Mar Ionio (da Capo d'Otranto a Capo Passero) realizzate nel periodo 1985-1997. Biol. Mar. Medit., 5(3): 120-129.

Tursi, A., F. Mastrototaro, A. Matarrese, P. Maiorano and G. D'Onghia. - 2004. Biodiversity of the white coral reefs in the Ionian Sea. Chemistry and Ecology, 20(Suppl. 1): 107-116.

Tursi, A., A. Matarrese, G. D’Onghia, M. Panza, L. Sion and P. Maiorano - 1994. Considerazioni sullo stato di sfruttamento delle risorse demersali (Capo d'Otranto - Capo Spartivento). Biol. Mar. Medit., 1(2): 95-104.

Tursi, A., A. Matarrese, G. D’Onghia, M. Panza, P. Maiorano, M. Basanisi, F. Perri, C.A. Marano and F. Casamassima. - 1996 Density, abundance and structure of population of red shrimps, Aristeus antennatus and Aristaeomorpha foliacea, in the Ionian Sea (Southern Italy). E.C. Final Report Contract MED92.015 DG XIV: 264 pp.

Tusseau-Vuillemin, M.H., L. Mortier and C. Herbaut. - 1998. Modelling nitrate fluxes in an open coastal environment (Gulf of Lions): Transport versus biogeochemical processes. J. Geophys. Res., 103(C4): 7693-7708.

Vamvakas, C. - 1970. Peuplements benthiques des substrats meubles du sud de la Mer Egée. Tethys, 2: 89-129.

Vamvakas, C. - 1973. Aperçu critique de la biocenose de vase profonde. Rapp. Comm. Int. mer Médit., 22(4): 119.

Vanney, J-R. and M. Gennesseaux. - 1985. Mediterranean Seafloor Features: Overview and Assessment. In: D.J. Stanley and F-C. Wezel (eds.), Geological evolution of the Mediterranean Basin, pp. 3-32. Spring-Verlag New York, Inc.

Van Harten, D. - 1987. Ostracodes and the early Holocene anoxic event in the Eastern Mediterranean: evidence and implications. Mar. Geol., 75: 263-269.

Vetrano, A., G.P. Gasparini, R. Molcard and M. Astraldi. - 2004. 
Water flux estimates in the central Mediterranean Sea from an inverse box model. J. Geophys. Res., 109, C01019.

Vincx, M., B.J. Bett, A. Dinet, T. Ferrero, A.J. Gooday, P.J.D. Lambshead, O. Pfannkuche, T. Soltwedel and A. Vanreusel. 1994. Meiobenthos of the Deep Northeast Atlantic. Adv. Mar. Biol., 30: 1-88.

Viudez, A. and J. Tintoré. - 1995. Time and space variability in the eastern Alboran Sea from March to May 1990. J. Geophys. Res., 100: 8571-8586.
Wezel, F-C. - 1985. Structural features and basin tectonics of the Tyrrhenian sea. In: D.J. Stanley and F-C. Wezel (eds.), Geological evolution of the Mediterranean Basin, pp. 153-194. Spring-Verlag, New York, Inc.

Weikert, H. and R. Koppelmann. - 1993. Vertical structural patterns of deep-living zooplankton in the northeast Atlantic, the Levantine Sea and the Red Sea, a comparison. Oceanol. Acta, 16: $163-177$. 